\title{
Mulemba
}

Revista Angolana de Ciências Sociais

5 (10) | 2015

Angola 40 anos de independência: memória, identidades, cidadania e desenvolvimento

\section{Rethinking the 1961 Baixa de Kassanje revolt: Towards a relational Geo-History of Angola}

Repensando a revolta da Baixa de Kassange de 1961: Rumo a uma geo-história relacional de Angola

Aharon de Grassi

\section{OpenEdition}

Journals

Electronic version

URL: http://journals.openedition.org/mulemba/1807

DOI: $10.4000 /$ mulemba.1807

ISSN: 2520-0305

\section{Publisher}

Edições Pedago

\section{Printed version}

Date of publication: 1 November 2015

Number of pages: 53-133

ISSN: 2182-6471

Electronic reference

Aharon de Grassi, "Rethinking the 1961 Baixa de Kassanje revolt: Towards a relational Geo-History of Angola", Mulemba [Online], 5 (10) | 2015, Online since 10 October 2018, connection on 26 January 2021. URL: http://journals.openedition.org/mulemba/1807 ; DOI: https://doi.org/10.4000/mulemba. 1807 


\title{
Rethinking the 1961 Baixa de Kassanje revolt: Towards a relational Geo-History of Angola*
}

\begin{abstract}
Aharon de Grassi* ${ }^{* *}$
Abstract: Through a geographic and relational reinterpretation of the start of armed nationalist struggle in Angola, this article helps to critique and move beyond common interpretations of Angola (and Africa more generally) as characterized by long-standing socio-spatial divisions. Rather than an economic protest in an enclave, the so-called «cotton revolt» actually had multiple aspects - some explicitly nationalist - in a mobilization that was forged through multiple connections spanning urban and rural areas, Malanje and Luanda, and Angola and the newly independent Congo. The revolt happened at Malanje's transforming crossroads of an underground Luanda-Malanje political network of churches, contracted laborers and administrative personnel that intersected with Congo-based provincial political mobilization organized through transborder ties. These combined nationalist networks articulated primarily but not exclusively with discontented peasants who faced joint state-corporate attempts to use intensified labor, spatial restructuring, control, and risks to overcome resistance and stagnating cotton production. These patterns and the ways that the colonial government and settlers responded with farm mechanization, infrastructure and regional development as counter-insurgency measures would partly shape post-independence rural development projects, and, ultimately, also now post-2002 national reconstruction. Rethinking the Baixa de Kassanje revolt in relational, geographical, and historical terms allows a more accurate understanding of the trajectories of Angolan and African political economies, and hence effective avenues for progressive social change.
\end{abstract}

Key-words: Angola, nationalism, rural, Geography, cotton.

* The text of the present article is an edited version of chapter three of my doctoral dissertation in geography submitted on 14 August 2015, at the University of California, Berkeley, United States of America. I thank the journal Editor for the opportunity and insistence to publish in Angola, where, from November 2010 to October 2012, research was conducted. I thank all the people mentioned in the dissertation, and also the Program in Agrarian Studies at Yale University for a post-doctoral fellowship that helped facilitate the revisions.

${ }^{* *}$ Independent Researcher. 
Through a geographic and relational reinterpretation of the start of armed nationalist struggle in Angola, this article helps to critique and move beyond common interpretations of Angola (and Africa more generally) as characterized by long-standing socio-spatial divisions between enclaves of coastal creole elite and the impoverished hinterlands that they purportedly dominate through combinations of force, patronage, and/or neglect (BAYART 1993; Messiant 1998; Herbst 2000; Vidal 2002; Chabal 2002; Cooper 2002; Kyle 2005; Ferguson 2006; Soares de Oliveira 2015). Drawing on a range of important sources that have hitherto been unused or under-used, the paper makes a range of contributions to the agrarian history of Angola, African geography, spatiality in theories of African political economy, relational geography, and to histories of nationalism, gender, colonial concessions, churches, cotton, and rural protest in Africa. ${ }^{1}$

Contrary to most prevalent histories of Angola - academic, official, and colonial - Angola's armed nationalist struggle appears to have been first launched in Kassanje, preceding the famed prison attack in Luanda on February 4th, 1961. The key Kassanje revolt in northern Malanje Province that began more than a month earlier is conventionally (mis)portrayed as a colonial massacre of farmers protesting particular economic abuses by a foreign company operating a concession in a purported enclave of the Kassanje lowlands («baixa») where it had the state-delegated exclusive right of purchasing of farmers' cotton. ${ }^{2}$ Although there were attempts to enforce certain enclavist provisions, in practice these and other activities involved much more dynamic and layered geographies of connection. The so-called «cotton revolt» was actually also a polysemic - and often explicitly nationalist - mobilization forged through multiple

1 New sources include unpublished Junta de Exportação de Algodão reports from the Arquivo Histórico Ultramarino (AHU) and Arquivo Histórico Militar (AHM), unpublished internal Cotonang reports from Banco Nacional Ultramarino archive, Banco de Angola annual reports for Malanje, and the Angola Norte newspaper, and revisited sources include the Boletim Oficial, the revolt files at AHU (MU/ GM/GNP/052/Cx.3), and the Anuário Estatístico.

2 The designation «Baixa de Kassanje» is not an indigenous term, and is used throughout the text to refer only to the region during the colonial period around the eastern lowlands of the old «Malange District», rather than the previous historical political formations, known as the Kasanji State, on which more careful study is greatly needed (particularly given the varying use of terms by different people, Cassange and Cassanje most often in the colonial period, and Kassanje or Kasanje since then) (see Miller 1972; KaMABaya 2007). 
connections spanning urban and rural areas, Malanje and Luanda, and Angola and the newly independent Congo. The revolt happened at Malanje's crossroads of an underground Luanda-Malanje political network of churches, contracted laborers and administrative personnel that intersected with Congo-based provincial political mobilization organized through trans-border social ties. These combined nationalist networks articulated primarily but not exclusively with discontented peasants who faced joint state-corporate attempts to use intensified labor, control, and risks to overcome resistance and stagnating cotton production.

This relational account provides an important corrective to $\mathrm{Lu}-$ anda-centric accounts of nationalism, and interpretations of the revolt that focus on parochial, economic, millenarian, enclavist aspects and therefore occlude not only the processes and connections that were the proximate triggers of the nationalist revolt in Malanje, but also the sedimented longer-term spatial processes that produced the structural conditions of interlinked agrarian intensification and nationalist networking. I conclude by briefly arguing that such a relational account also helps to comprehend how, since the end of war in 2002, contemporary socio-spatial patterns oil-windfall spending and governance throughout Angola have been profoundly shaped not simply by coastal elites' patronage and exploitation of hinterlands and interior enclaves, but also by some important geographic legacies of subsequent dynamics following the 1961 revolt and start of armed nationalist struggle - namely, mechanization, counter--insurgency logistics, and regional development initiatives.

It was during fieldwork - when an elderly soba (chief) offhandedly mentioned to me, between bites of fresh sweet cassava while we took a break from weeding his intercropped rows in western Malanje that he too had been arrested after the 1961 revolt - that I began to really appreciate that the dynamics of the revolt were not restricted, as commonly perceived, to the Baixa lowlands in the east. Later, when I heard on the nightly news of the provincial radio station that the author of a recent book about the revolt would be speaking at Malanje's agricultural college at Quéssua (Keswa) near the old American Methodist mission and school, I set out early and headed to the amphitheater at Keswa built by Cubans and reconstructed by Chinese. ${ }^{3}$ This book - the first participant's extended account of the

3 Note, I have tried to use post-independence Bantu spelling, substituting K for Q, and hard C's. 
revolt - delicately but insistently showed the distinctly nationalist (and not only anti-colonial) character of the mobilization and revolt, and I have tried to carefully assess, situate and build upon this otherwise yet unappreciated work.

Since much of the revolt's basic aspects and chronology have been described by other authors (who sometimes draw selectively on each other), I will not rehearse them in detail here (see MARCUM 1969; PÉLISSIER 1978; FreUdenthal 1999; Kamabaya 2007). ${ }^{4}$ Instead, I will here provide a very brief summary in order to be able to then use a discussion of further details to point out the varying ways that different people have interpreted the revolt, and present my own new, geographical interpretation. I am specifically drawing on and developing a critical geographical conceptual approach that emphasizes that social relations are always also spatial relations, mutually produced through multiple temporal and spatial scales. ${ }^{5}$

In the Baixa de Kassanje in the eastern part of the Province of Malanje, some $500 \mathrm{~km}$ east of the capital Luanda, black alluvial soils fed by north-flowing tributaries of the Congo River were used by African farmers under Portuguese colonial compulsion to grow cotton for sale since the 1930 , as well as to pay obligatory colonial taxes. The Portuguese state allocated concessions with the rights to recruit labor and promote, purchase, and process cotton in the area to a company (the Angolan General Cotton Company, known by its

4 As a controversial topic, the revolt has also attracted more study with some new insights but still needing more systematic analysis: Buijtenhuijs (1991), Camacho (2002), Cann (2011, 2012, 2015), Curto and Cruz (2012), Freudenthal (2012), Keese (2004), Mateus (2011), Pitcher (1991), Silveira (2013), Paredes (2015: 202-24), Antunes (2015). Generally un-sympathetic pieces by Portuguese military officials that discuss Kassanje in relation to the anti-colonial war more generally include Rebocho Vaz (1993), EME (1998), and Nunes (2005). There is still a great deal of research to be done on the revolt, including locating more of the archives of Cotonang, the Junta de Exportação de Algodão, and the Instituto de Algodão de Angola, consulting the Operations Reports of the Portuguese Army, as well a thorough review of relevant materials in the AHNA and AHU, the Holy Spirit mission archives, and oral history in the region (particularly regarding gender and women) (see also Miller 1972). See also the excerpt from the video «A Guerra: Part 7», by Joaquim Furtado, at https://www.youtube.com/ watch? $v=$ f7up $6 \mathrm{w}-\mathrm{a} 3 \mathrm{Fc}$.

5 This contrasts with Weberian notions of determination through the interaction of abstractly discrete units. See e.g. Massey (1994), Lefebvre (1991), Hart (2002), Goswami (2004), and cf. also Cooper (1994) and Terretta (2013). 
Portuguese acronym, Cotonang) held by about a dozen mostly Portuguese and Belgian interests. ${ }^{6}$

The main period of active revolt ran from January of 1961 through March, though since December people had been resisting, slowing down their work, «killing white animals, refusing to pay taxes and sow cotton» (FREUDENTHAL 1999: 283). January was the beginning of the cotton planting season, and farmers and non-farmers also refused administrative orders. The first incidents began in January as officials returned from Christmas break. On January 4th there was unrest evident around four villages where discontent with state sepoys - «cipaios» - had simmered for years, just a few kilometers north of the administrative and commercial cotton post Milando. ${ }^{7}$ Villagers tried to tie up a local interpreter for the state, but his accompanying cipaio intervened, and the two African functionaries returned to the administrative post confirming rumors frightening the state staff (MoNTEIRO, op. cit.). Villagers continued organizing amongst themselves, and then on the 12th, after villagers again refused cipaios' orders about taxes and cotton and threatened to kill

6 Cotonang abbreviates Companhia Geral de Algodões de Angola. The main shareholders were the Banco Nacional Ultramarino, Banque Josse Allard, Banco Burnay, Banque de Bruxelles, Fomento Geral de Angola, and Association Cotonnier de Belgique (untitled, BNU archives). A tax of 70 Angolares was imposed in 1930 with the creation of a Cotton Intendancy in Kassanje, and a 1928 law had expanded to Kassanje the regime of compulsory cotton cultivation hitherto enforced elsewhere in Angola, requiring each house to cultivate 20,000 plants on at least half a hectare, spaced 25 centimeters apart in lines 1 meter wide (see Diploma Legislativo 242; Diploma Legislativo 5 of 28 September 1928 expanded to Kassanje the Diploma Legislativo 638 of 24 September 1927, which in turn expanded to Luanda, Ambriz, Quissama, Porto Amboim, and Novo Redondo an earlier law focused on Icolo e Bengo, namely Portaria 760 of 21 November 1908 that had required 2,500 cotton plants on at least a half hectare). Obligatory cultivation was extended in Portaria 6916 of 1949 and Despacho of January 5, 1949, at 0.85 ha of cotton and 1 ha of food per family, and 0.25 ha each of cotton and food for elderly men and single women (these were apparently raised, but it is not clear when and which legislation). See also Beatriz (1918) on Icolo e Bengo. On the importance of taxes in motivating cotton cultivation by what were viewed in racist stereotypes as «lazy» Africans, see the report by Cotonang Director General Henrique Valdez (1932).

7 The villages were Ganga Muchica (Nganga Muxika), Quivota (Kivota), Mulundo (Mulundu), and Gombe (Ngombe). See esp. «Instruções secretas: Às autoridades administrativas da Circunscrição do Cambo», Governador Júlio Monteiro Júnior, January 11, 1961 (AHU). On the discontent, see Freudenthal (1999: 279). 
them, that night a new mestiço Cotonang agent was killed when crossing into one of the resisting areas at night. ${ }^{8}$

Soon throughout the Baixa, people blocked roads, damaged stores and Cotonang and administrative buildings, and destroyed their identification cards and cotton seeds. They variously threatened to attack anyone who tried to force them to work for the company and the state, would not pay the annual head tax nor obey the local administrator, and stated that they had been slaves of whites for 500 years but were now free, and would only take orders from Kasavubu (the President of the Congo at that time) by way of his messenger Maria. The colonial government scrambled police and military forces, but - wary of negative publicity, given the presence of journalists in Luanda covering a hi-jacked sea liner, and impending debates at the United Nations about continued Portuguese colonialism and abusive labor practices - government officials first briefly tried talking with the protestors, which apparently only emboldened them. Official reports show indications of the revolt then occurring quickly across various areas, initially around the northern center of the Baixa near Milando and the Lui River, and then indications of thousands of people mobilized across a large area of approximately $150 \mathrm{~km}$ by $200 \mathrm{~km}$, involving dozens of towns and villages, stretching from near the Congo border and Kwango River around Tembo Aluma to south past Xa Muteba, and spanning from west of Bange Angola to east of Luremo.

Violent Portuguese military repression of the revolt lasted from early February through March at least, and consisted of two units from the Portuguese army, as well as air force surveillance and bombing raids. ${ }^{9}$ After a high-level meeting was held in Luanda on January 18th, and further monitoring and negotiations were held, an army unit was sent from Luanda to Malanje on February 4th. Another army unit had left from the provincial capital, and encountered armed resistance, with bombing raids reported on February 5 th. On February 8th they reported that some 10,000 armed Angolans

\footnotetext{
8 Martins, M. (1961) «Apontamento 14: Os incidents da Baixa de Cassange», January 30, p. 9; Informação 262, March 7, 1961, p. 2 (AHU).

9 There were some Angolans listed in the 4th Companhia de Caçadores Especiais, though the timing of their participation is not clear. See «Livro de Efectivos da 4CCE», at <http://4cce.org/photos/livro-efectivos-4cce-cpt-t-morais-ed.pdf>.
} 
in the revolt had gathered near Kunda dia Base. ${ }^{10}$ The precise total number of people killed during the revolt is disputed and appears to have been deliberately obfuscated by the Portuguese at the time with a low partial figure of 243 , which has sometimes been uncritically repeated. ${ }^{11}$ The actual rough number of Angolans killed is very likely in the thousands, but difficult to know particularly because of the indeterminate number killed by Portuguese bombing raids (reportedly of approximately 17 villages), with various estimates of fatalities ranging up to a perhaps improbable 30,000. ${ }^{12}$ Freudenthal (1999: 267) summarizes figures of the toll of «7,795 injured, 4,876 prisoners, [and] 5,524 Angolans shot down (men, women and children)» (based on «Angolan testimonies» and citing a PIDE process).

Thousands more people fled across the border to the Congo or were arrested or injured by the time the area had been re-conquered by the colonial government, at which point subsequent major connected nationalist armed revolts had also occurred in Luanda (February 4th) and in the coffee areas to the north and west of Malanje (March 15th onwards). The legacy of the revolt continued somewhat across Malanje in the years immediately after the revolt in the form of dozens of minor political incidents and threats. ${ }^{13}$ And

10 Martins, M. (1961), «Apontamento 34: Incidentes da Baixa de Cassange (II)», March 7, p. 15.

11 Cann (2012: 515, 2015: 64) states unequivocally «For the mutineers there were 243 deaths», citing EME (1998: 150), which cites the February 281961 Boletim de Informação of the 2a Rep/RmA for the period January 11 to February 27, reprinted in Lara (1999: 684-693). However, a March 9 telegram from Angola's Governor Geral to the Overseas Minister's office with the title «Malange Events - number of dead and injured» states that not only were there 243 deaths verified directly, but also besides this there were deaths resulting from airplane attacks that can't be determined (AHU). Symptomatic of some of the difficult issues in accounting of fatalities, EME (1998) says nothing of the air bombing on February 18th around Marimba Anguengo, for which Freudenthal mentions possibly 500 deaths, based on "Apontamento 34», p. 20, which reads, «A Companhia pede apoio aéreo sobre a povoação de Marimba Anguengo onde se encontram cerca de 500 indígenas com o cabecilha Gamboa (?)».

12 Cann (2012: 509) also notes «The officer would fly with a box of grenades between his feet and, when required, drop one into the center of a threatening mob from the open window of the aircraft as it swooped low. On three days in February, the 18th, the 23rd, and the 24th, grenades were dropped, causing losses and panic in the bands of rebels. From the perspective of the ground forces, this "bombing" had not been requested and proved counterproductive, as it caused many unwanted casualties". Cf. also the Portuguese unit veterans' website, «4. ${ }^{\text {a }}$ Companhia de Caçadores Especiais», <http://4cce.org/index.html>.

13 See AHU, AHм reports, and «Relatório Perintrel, n. ${ }^{\circ}$ 22/64 da SCCIA - Malange (Angola)» (PT/AHD/MU/GM/GNP/RNP/O408/01838). 
the nationalist armed struggle that began in Kassanje would continue in the broader region as some 10,000 refugees from the Baixa settled around the nearby Panzi District in the Congo and formed «a revolutionary support base for UPA [Union of Angolan Peoples] military operations back into Kasanje» (MARCUM 1969: 126). ${ }^{14}$

Though the revolt occurred over 50 years ago, it is extremely relevant today, for three main reasons. The revolt informs popular debates about history and present problems in Angola, it sits at the center of academic and policy interpretations of political economy in Angola and Africa, and it suggests a rethink of some conceptually foundational work in African studies.

Figure 1. Map of the Baixa de Kassanje, c. 1960

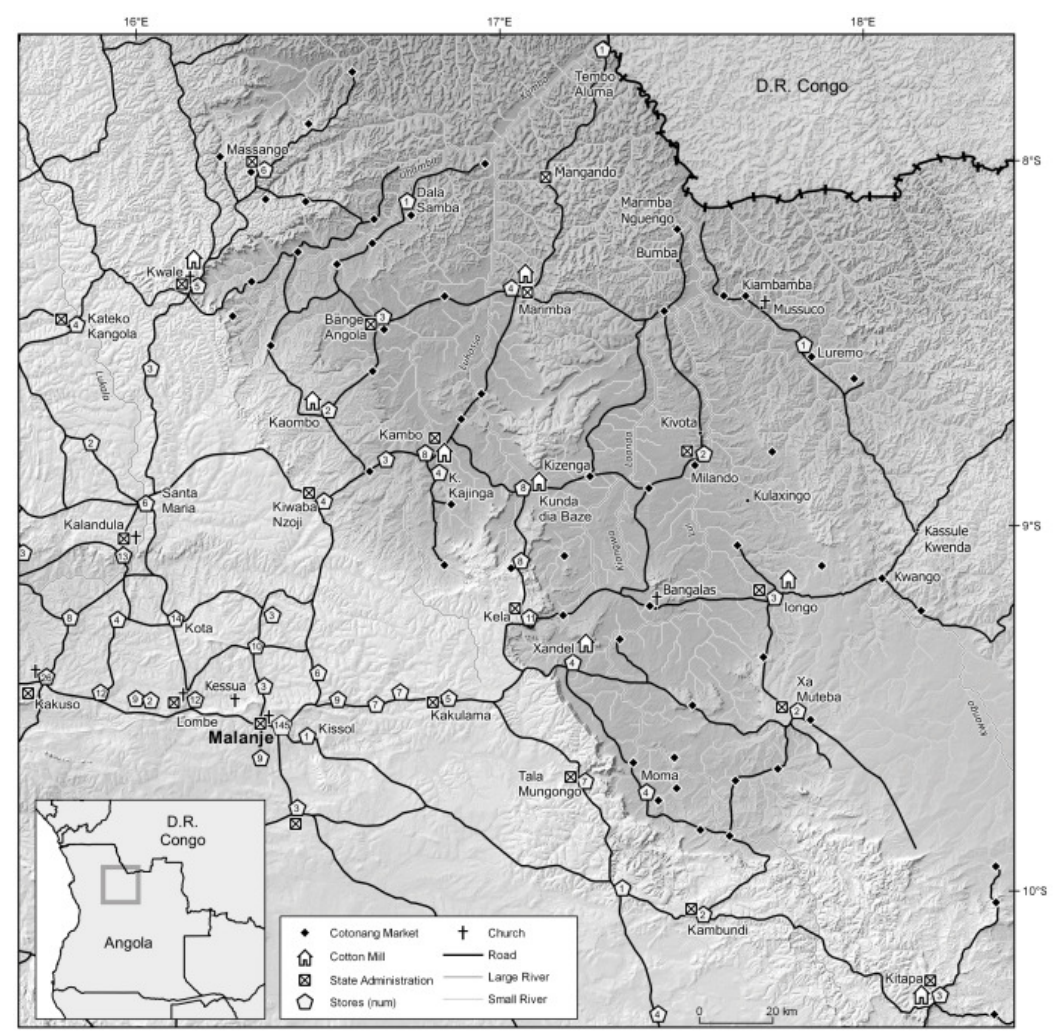

Sources: «Baixa de Cassange», Cotonang (AHU), Banco de Angola (1958)

14 As João César Correia later recounted, «The people that fled to the Congo, the sobas, Soba Marimba, Soba Chiquita, various sobas fled with their people. Then we gathered together these people and mobilized them for a struggle capable of invading Angola [on March 15th]» (see «A Guerra», op. cit.). Such connections also contradict Macey's (2012: 386-388) portrait of adventurism. 
Figure 2. Cotton production, number of farmers, and area in Baixa de Kassanje, 1927-1960

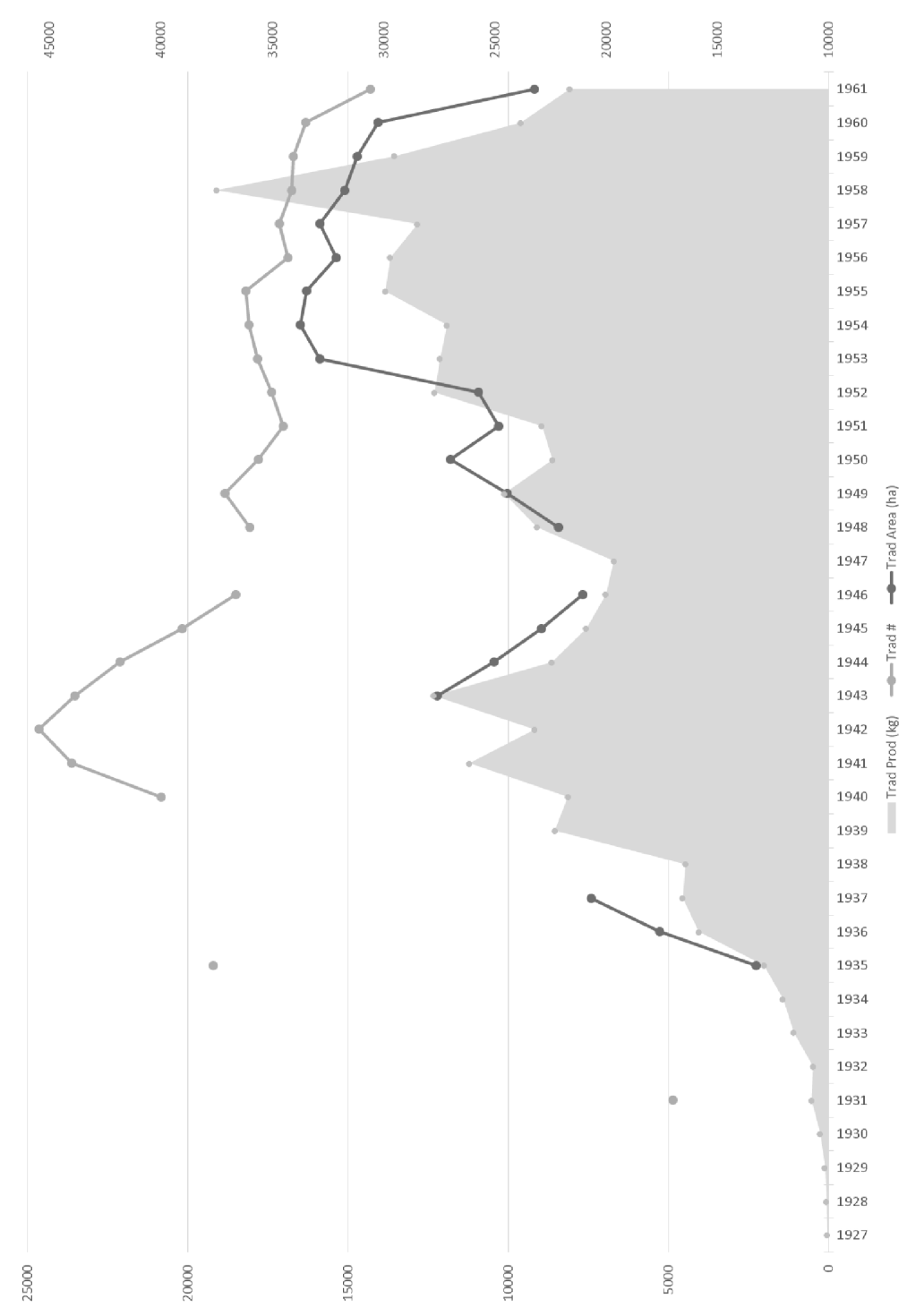

nb: grey shaded = production (left axis, $\mathrm{kg}$ ), dark grey = area (left axis, ha), light grey $=$ number of producers (right axis)

Sources: Cotonang reports, DSPCFT (1938: 22), Valdez (1932), Anuário Estatístico, \& Agricultural Services Bulletin. The graph retains the 1955-60 figures for Camaxilo, which was transferred from Malanje to Lunda in 1955. The 1940-1942 numbers cultivators are estimates stated in Cotonang reports. 


\section{The Baixa de Kassanje in debates and challen- ges in Angola}

Over recent years, prevailing discourses in Angola about the Baixa de Kassanje revolt have begun to be revised, including by some state officials, to move away from prior depictions of the revolt as simply a massacre by brutal colonial Portuguese rulers of parochial peasants protesting about their particular economic grievances - a disconnected prelude to the start of the nationalist struggle in Luanda on February 4th. The three problematic elements of this view are (1) the massacre was of more significance than the revolt, (2) the revolt was by isolated peasants or rural workers, and (3) the revolt was concerned only with particular economic grievances related to obligatory cotton cultivation in the Baixa de Kassanje. Some of the main tenor of this interpretation, which still often prevails, is illustrated in the statement issued by the ruling MPLA (the Popular Movement for the Liberation of Angola) party on the 5oth anniversary of the revolt:

«[...] The response of the colonial system to the desire of the humble peasants of the Baixa de Kassanje to have a more dignified life, based in better working conditions, resulted in an indiscriminate massacre by its Air Force, through dropping of "napalm" bombs.

That hideous act, from the mentors of the colonial system, provoked a deepening of the consciousness of everyone who was already fighting for the conquest of our liberty and motivated a greater cohesion in the midst of the nationalist resistance groups, defrauding the willingness of the faithful servants of the colonial system and transforming the Baixa de Kassanje uprising into a seed from which would sprout the first organized action, with political-military characteristics, led by the heroic combatants of February 4th $1961\left[\ldots . .{ }^{\mathbf{1 5}}\right.$

Post-colonial states emerging out of liberation movements sometimes grapple with harnessing, directing or limiting the potent

15 ANGOP (2011) «Press Release from the Political Bureau Secretariat of the MPLA relating to January 4th', Jan 4», <http://www.portalangop.co.ao/angola/pt_ pt/noticias/politica/2011/o/1/Nota-Imprensa-Secretariado-Bureau-PolíticoMPLA, 2eoe3061-7580-4e5e-9170-0c05409979ff.html>. It is hard here not to be reminded of Fanon (1963: 113, 114). 
significance of liberation rhetoric, histories, and claims. However, as the war years recede in Angola and public discussions increase, exclusive claims to nationalist origins have weakened in favor of recognizing various contributions made to the anti-colonial struggle, including by Kassanje peasants. ${ }^{16}$ In addition, the emphasis on colonial and foreign brutality has also given way to more of an appreciation of the complex social transformations in Malanje. ${ }^{17}$ The rural concerns and family backgrounds of leading nationalist state officials have also gained publicity, particularly as the state grapples with trying to use oil revenues to boost agricultural development in order to reduce poverty and growing urban concentrations and to diversify the economy. In this respect, a nationalist recasting of the Kassanje revolt bolsters claims by current rural residents of the Baixa de Kassanje to a portion of the vast oil wealth, not to mention constituting an implicit critique of inequality.

For several years, plans for spectacular new projects in some areas of the revolt - including a model village, social centers, infrastructure, etc. - have been discussed, building on the yet unfulfilled promises made by Angola's first president on a visit to the area in August 1979. ${ }^{\mathbf{1 8}}$ Such pronouncements of plans and projects serve as opportunities for publicity about purported commitment to rural development, but also are an ambivalent encounter in which people make implicit (and sometimes explicit) critiques of the government's lack of fulfillment of obligations and prior promises, and even outright immoral enrichment.

For example, in 2013 a historian was cited by the more independent Radio Ecclesia, asserting continuity between the peasants' struggle and current struggles for social justice and redistribution: "It is necessary that we continue to go for social justice, love for one's neighbor, know how to share the riches of the country $[\ldots] »{ }^{19}$

16 See perhaps Conceição Neto (1995) «Primeiro, primeiro, foi Janeiro: Guerra e "Memória"», Correio da Semana (Luanda), January, cited in Freudenthal (2012: 15). Cf. also fn. 13.

17 Notable, for example, is Santos' (2005) scholarship on the growth of the city of Malanje.

18 Reported in Jornal de Angola.

19 Even he, though, limits their grievances to «precarious life conditions». E.g. (2013) «Sobreviventes dos massacres da Baixa de Kassanje querem melhoria das condições de vida», Radio Ecclesia, Jan 4, <http://www.radioecclesia.org/ index.php?option=com_flexicontent\&view=items\&cid=198: sociedade\&id=11809:sobreviventes-dos-massacres-da-baixa-de-kassanje-querem-melhoria- 
Similarly, a spokesman for National Association for the Baixa de Kassanje stated that people there were requesting solutions to many problems, including «potable water, schools, health services, roads, bridges, rehabilitation of infrastructures supporting cotton production that have been inactive for half a century». He noted specifically:

«The construction of primary and secondary schools, as well as intermediate institutes, the construction of municipal hospitals and maternity wards, construction of adequate social housing for the community with more than 60 years, the implantation of the program 'water for all' and basic sanitation in the whole region. The registration of survivors of the struggle against colonial repression, January 4th 1961, in the process of integration in the class of veterans for the pension fund».

And the secretary of information for the main opposition party, UNITA, was summarized as saying «that the commemoration was a homage to all who fought against colonialism and for national independence», and he went on to say, in what could be read as an implicit critique of government inaction, "We now have to have capacity to give dignity to the survivors of this act. In the last few years people have made [this] manifest, asking for greater dignity for the survivors and inhabitants of that region ${ }^{\mathbf{2 0}}$

In addition to debates over nature of the revolt, the aftermath of the revolt is also critical to understanding contemporary plans and practices of reconstruction and development. There was subsequently a major push by the Portuguese to promote regional development projects to appease grievances and avoid nationalist sympathies, to mechanize cotton production and thereby lessen reliance on indigenous labor, as well as to construct massive amounts of new

-das condições de vida», Radio Ecclesia, Jan 4, <http://www.radioecclesia.org/ index.php?option $=$ com_flexicontent\&view $=$ items\&cid $=198$ : sociedade\&id $=1180-$ 9:sobreviventes-dos-massacres-da-baixa-de-kassanje-querem-melhoria-das--condicoes-de-vida\&Itemid=716\#.UxPIkoWKiFc $>$; Soares, Isaías (2011) «Há descontentamento na Baixa de Kassange», Voice of America, Jan 5, <http:// www.voaportugues.com/content/article-01-04-2010-baixadokassange-voanews-112882484/1259240.html>; (2011) «Projecto piloto não vingou», O País (Luanda), Aug. 22.

20 ANGOP (2007) «O4 de Janeiro de 1961 catapultou os nacionalistas para o movimento libertador», Jan 3. 
roads for marketing and counter-insurgency military logistics. These extensive development plans that emerged as a colonial response to this revolt, the others, and the general launch of armed liberation struggle have been picked up by the post-colonial government since the end of the war in 2002 as influential guides for funneling billions of dollars of oil revenue into reconstruction and rural development.

In sum, the discussion over the character of the revolt is also a proxy for other debates, including about moral claims to dignity and a share in national development. The revolt's aftermath shaped current plans for reconstruction and development, which are also occasions for these continued debates.

\subsection{Academic and policy interpretations of political eco- nomy in Angola and Africa}

Many academic analyses have uncritically repeated the narrow economic or Portuguese propaganda-influenced interpretations of the Baixa de Kassanje and the revolt. Moorman's (2008) otherwise excellent social history, for example, says that Malanje cotton producers "rebelled against the system of forced cotton production" (81) but says nothing of their nationalist aims. A popular tourist guide to Angola notes that the revolt was by «workers» who "protested violently against appalling working conditions and forced labour» (295). The pastor Malcom McVeigh (1961), seeking to garner sympathy for purportedly innocent and humble peasants, explicitly denied political overtones: "It is a mistake to consider these [MPLA and UPA] foreign or Communist movements [...]. It was a spontaneous demonstration against abusive practices by the Cottonag [sic] Company $[\ldots] » .{ }^{\mathbf{2 1}}$ For many years one of the best textbooks on Angolan history was that of Wheeler and Pélissier (1971: 174), which notes in passing the possibility of political, religious, and Congolese influence, but the book generally portrayed the revolt simply as «an act of defiance against the system of obligatory cotton cultivation for which Cotonang, a monopolist company, had the concession in

\footnotetext{
21 UPA is União das Populações de Angola, a group amongst others that emerged in northern Angola, Luanda, and the Congo, and would become the FNLA (Frente Nacional de Libertação de Angola), led by Holden Roberto (MARCuM 1969).
} 
the region east of Malanje [...]. This was a rebellion of poverty; it failed because the rebels lacked arms and leaders and support from neighbouring tribes». Newitt (1981: 228-229) cites Pélisser (1978) to dismiss the revolt as a "peasant jacquerie» that was done by «local groups», was «almost totally unorganized», and «took the nationalist leaders as well as the authorities unawares». ${ }^{22}$ One of the most esteemed detailed analyses of the conditions leading up to 1961, Christine Messiant's 1983 doctoral thesis likewise inaccurately describes,

«degraded by misery, traditional society there was preserved, and this preservation, given the specter of famine, can explain why the revolt extended, at the beginning of 1961, to the whole region. Without local cadres, without connections with the movements that developed at the time in the Congo and Luanda, the revolt would be crushed [...] [T] he Baixa [...] [was] an enclave of pure exploitation where only a revolt without hope or escape was possible» (MESSIANT 1983: 263, emph. added). ${ }^{\mathbf{2 3}}$

And Marcum's (1969) otherwise brilliant and extensive chronicle calls the uprising «spontaneous and localized» (126), while Cann's (2015: 65) recent but problematic account also calls it «spontaneous and localized». ${ }^{\mathbf{4}}$

${ }^{22}$ He writes «nationalist leaders were entirely taken by surprise when urban guerrillas began action in Luanda and when a peasant jacquerie broke out in the Baixa de Cassange cotton growing region in 1961. To this day no one really knows which group, if any, had a hand in organising these risings. However the exiled nationalist leaders hastened to claim credit for the action, to claim their responsibility and to try to use the events to their advantage. But it was all very much being wise after the event».

23 Messiant cites Pélissier (1978: 409-424) what she says is «isolation from nationalist organizations, by which it was certainly not organized, although there has been, through men including a messianic leader, Congolese influences».

24 Birmingham (1992: 35) mentions only rural «anti-colonial despair». He moreover erroneously puts Kassanje in the east of Angola, and says the revolt had been contained by the police in January (but it was the army who did the repression, and they actually only arrived in February). See also Wright (1997: 60), who says the March coffee revolt was in the «Baixa de Cassange». Symptomatically, Soares de Oliveira (2015: 220), despite the present author's direct communication on this point, nevertheless erroneously writes that the revolt was by cotton «workers», confines it to January, and states that it «seems to have been similarly unrelated to the liberation movements» (referencing KeESE 2004). 
The nuances of contemporary Angolan debates discussed in the previous section about the meaning of the revolt in relation to current projects are not sufficiently appreciated in most academic and policy interpretations of Angola's political economy. Perhaps this is partly because of a lack of sensitive on-the-ground study in Angola outside of Luanda. ${ }^{25}$

Perhaps more important though is the problematic framework used to understand political economy in Angola, which is then often depicted as a particularly extreme or clear example of dynamics that are characteristic of Africa more broadly (See page 30). The essential dynamic is usually perceived as one of a neopatrimonialrentier-gatekeeper state, in which a regime of cosmopolitan state, party, and business elites in the coastal capital cities profit by controlling trade and the proceeds of allocating valuable enclaves to foreign companies, and retain power by using such wealth to buy off political support through selective patronage, repression where needed, and otherwise neglect of the mass of low-productivity farmers. In this sense, the delimited foreign cotton concession covering the Baixa de Kassanje, would be understood as a prototypical enclave. An indicative account for Angola that builds on many of the above approaches and specifically cites the Kassanje cotton area is given by Soares de Oliveira (2013: 168):

«the Portuguese systematically resorted to the "discharge" of state responsibilities [...]. The Portuguese also gave concessions to private corporations that became de facto sovereigns within their domains of extraction [...] the administrative and financial means to replace them did not exist. Three companies stood out: СCFB, which ran the Benguela railway, Cotonang, the cotton firm in Malange [sic] district; and above all, Diamang, the multinational mining consortium in Lunda district». ${ }^{\mathbf{2}}$

25 Ferguson (2005: 381), for example, notes, «The highly simplified sketch I present here has its uses (I hope), but it cannot stand in for the detailed ethnographic accounts that, one hopes, will soon help to give us a more fleshed-out picture of the social and political life of African mineral-extraction enclaves».

26 Likewise, Cooper (2002) makes no mention of Kassanje. And Reno's (2011) history of warfare discusses Angola (pp. 64-67), but ignores Kassanje and otherwise confuses facts and chronology of the 1961 revolts. On concessionary politics more generally, cf. Hardin (2011). 
Consequently, a critical rethinking of such portrayals of the Baixa de Kassanje and the revolt has much broader implications for theory and practice in Angola and Africa.

\section{Reconsidering Angola's Baixa de Kassanje and 1961 revolt: A crossroads in transformation}

Malanje's role as a transforming crossroads gave rise to the revolt as the beginning of armed nationalist struggle. The revolt was shaped by complex, intensive, long-standing socio-political relations with the Congo (which achieved independence six months prior, in June 1960), but accounts of the Baixa de Kassanje revolt have downplayed these relations, ignored them, or depicted them as simply «outside agitation». Connections between Malanje and Luanda were also key to the revolt, and though sometimes recognized, the extent and nature of these relations have also been under-appreciated. The revolt was also shaped by profound transformations in Malanje and the Baixa de Kassanje, which have not yet been closely analyzed. The argument therefore contributes to several different discussions - about the origins of nationalist struggle in Angola, about space in African political economy, and about the contributions and character of relational geographies.

The discussed relations are not simply between cities as discrete points, but rather I conceptualize these places and others using an expansive notion of place. Places are not entirely circumscribed points connected linearly somehow through an ether, but rather are constituted through the grounded sets of geographies - for example, heading inland east from Luanda, the cotton area of Catete, the sugar plantations in Caxito, racialized coffee hills of Dembos, the Dondo market center, the American mission at Kessua, the fort and mines at Pungo Andongo, etc. I emphasize the multiple connective places through which the concentrations in Luanda, Malanje and Congo are related. I then hope to identify some of the key turning points in transformations of the processes by which Luanda and Malanje have related to one another through these spaces. 


\section{Malanje-Congo relations}

Before turning to Malanje-Luanda relations, I want to emphasize various sorts of relations between the regions of Malanje and southern Congo. Like the above critique of discrete notions of Malanje and Luanda as circumscribed cities, my analysis of Congo-Malanje relations is also partly a critique of notions of discrete socio-spatial distinctions between what has been called a relatively homogenous Kimbundu-speaking «Mbundu complex», contrasted with a Bakongo society to the north west, a Lunda-Chokwe society to the north east, and an Ovimbundu society to the south. As above, I am not conceptualizing a distinct Mbundu society that interacts with other societies. Rather, I am examining specific relations through which shifting groupings of people are (re-)formed and contested. As above, I analyze the relations of two places - Kinshasa (which the Belgians called Leopoldville) and Malanje - through analysis of processes producing other geographies, including those of smaller towns such as Kikwit, Tembo Aluma, and Marimba, and shifting ethnic-political formations (Bapende, Maholo, Mussuco, Jinga, Bondo, Imbangala, etc.). The relations between Kinshasa and Malanje that I emphasize are labor migration, political and social dynamics (pre-colonial formations, churches, political parties, etc), and commodity trade (rubber, palm oil, cotton, consumer goods, etc).

These spatial relations involved three historical turning points. In the late 1910 s and the 1920 s battles over trade routes and colonial occupation («pacification») shifted towards more extensive colonial presence and labor and tax exactions. The second turning point came after decades of these exactions as World War II and associated market disruption preoccupied colonial governments and finance, and some people left the Angolan areas of cotton intensification for the Congo, whilst others in the Congo sought refuge in Angola or in Kinshasa from Belgian exactions (others went to Angolan cities). The final key turning point came with the Congo's transition to independence in 1959-1960 and the related rise of Angolan nationalism, in which the deep and wide regional relations of labor migration and socio-political ties took on a distinct character of active, coordinated political mobilization.

The connections between Malanje and the Congo were interpreted in particular, delicate ways by both nationalist forces and the Portuguese colonial regime. The colonial regime sought to portray 
the revolt as easily swayed tribes duped by outside communist agitators from the Congo, thereby playing upon Cold War fears and tropes of peasant passivity and naïveté, whilst careful to not hint at too great a weakness of territorial control by the colonial state. Nationalists in exile sought to also portray their shadow administrations as coherent and informed, whilst emphasizing the victimization of the peasants by the brutal colonial regime in order to mobilize international action and support for their nascent government in exile.

Sobas and leaders of the revolt were reported by colonial officials to have expressed in unequivocal terms that they were in touch with «Pessa», that is, P.S.A., or the Parti Solidaire Africain, a Congolese political party that had boomed in the southern Congolese districts bordering on Malanje Province during the run-up to Congo's independence in June 1960. People in the Baixa had PSA calendars with the distinctive serpent and tree emblem, and reported receiving orders from PSA and Kasavubu via an intermediary Maria. ${ }^{27}$

The role of PSA however has gone relatively un-examined in accounts of Kassanje, despite a remarkable 1967 book by Herbert Weiss who used extensive travels and close cooperation to describe in detail the party's rise. The PSA was buoyed by popular discontent with rural Belgian colonial administration and, after riots in 1959 in the capital Léopoldville (Kinshasa), the forcible re-location of politicized urban youth back to their villages (See also LAMAL 1954). Weiss is at pains to point out that the PSA, led by the leftist Antoine Gizenga and Maoist Pierre Mulele (who would go one to lead widespread rural rebellions in 1964), was at first somewhat elitist and tentative, but the level of popular discontent exceeded the ability of the party leaders to conservatively channel it - «the leaders' hands were forced by local occurrences» (229). In manners very similar to the subsequent Kassanje revolt, rural people of the Kwango and

27 For example, soba Bumba reportedly stated, "All this "confusion" is not ours. We don't want anything to do with you whites, leave us alone to live our lives. Today, we only obey Kasavubu whose orders come to us by emissaries [...] If you whites want war don't do anything to us but rather to Pessa, Maria, and Kasavubu who are responsible for everything. You can kill us but we are innocent. This was the order that came to us from Fatim who created the world and all the people white and black. The General Governor of whom you speak should try to reach an understanding with Kasavubu [...] We are not the ones inventing anything and we only comply with orders». See Teixeira, op. cit. 
Kwilu districts in the neighboring Congo embraced PSA and refused to obey Belgian orders, pay taxes, perform obligatory labor, show respect, and so on (See also CANN 2015: 54). Weiss presciently recognized that such «rural radicalism» «clearly runs counter to the received view of the process of decolonization in Asia and Africa» (293), but such insight has thereafter been largely unappreciated by academics. ${ }^{28}$ However, some recent revisionist work on Cameroon, for example, draws together newly available archives and has illustrated the extensive deliberately cosmopolitan geographies of nationalist rural mobilization (TERRETTA 2013). To understand the ways by which the PSA, Kasavubu, Lumumba, and other aspects of Congolese independence came to have such an importance in Malanje requires examining the region's deep historical and geographical connections through kinship, political rule, and trade.

It is worth briefly foreshadowing that Congo-Malanje relations were also shaped by nationalists' networks that stretched both through Malanje to the Congo and from Luanda to the Congo and back down to Malanje. Key here was the figure of Malanje-born Andre Rosário Neto (discussed more in the next sub-section). Rosário Neto was a civil servant in finance and part-time journalist who studied in a church seminary in the Baixa de Kassanje, and then cultivated relationships with nationalists in Luanda during seminary school there, and subsequently joined the Union of People of Angola (UPA) in the Congo in June 1960, where he produced and translated from French into Portuguese and Kimbundu radio programs and printed newspapers and propaganda to reach Malanje and nearby areas (e.g. Figure 3 ). ${ }^{29}$

28 Boone (2013: 44) is exceptionally right to mention this work.

${ }^{29}$ See for example some of Neto's articles in Angola Norte: «30 dias em Malange», 1948/o9/25, "A juventude de Malange e o cinema»1949/04/02, «Um sintoma feliz: Uanga»1951/o9/o2, and «Já nasceu o menino Deus» 1951/12/22. The role of Neto's wife, Maria da Conceição, remains to be investigated, though she headed the women's wing of the FNLA in 1963 at least (CHILCOTE 1972: 108-9). The PSA was sympathetic to but also aimed to be broader than Lumumba's Mouvement National Congolais. Lumumba authorized weekly UPA broadcasts on Radio Léopoldville starting August 3, 1960, which emphasized unity, and distinguished between the Portuguese government and settlers (MARCUM 1969: 80). Cleveland (2008: 209-10) also mentions that diamond workers in the north-east would listen to Congolese and liberation movement radio broadcasts from the Congo (more so in the 1960s). 
The point of the below excerpt reprinted from this newspaper is to illustrate how what was supposedly a parochial Mbundu cotton worker revolt involved figures such as Neto who had links to the Congo and worked with people of different ethnicities and were keenly tuned in to broader global anti-colonial movements and consciousness.

Figure 3. Transnational news in Kimbundu in La Nation Angolaise
Figure 4. PSA Emblem

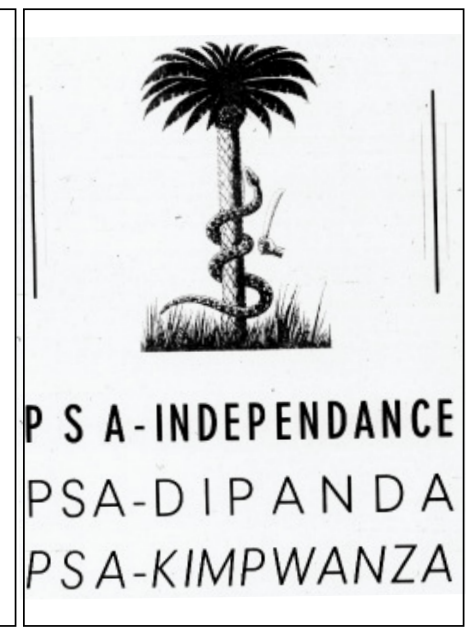

Source: Solidarité Africaine,

March 18, 1960, p.11.

\section{Jihundu ja Afro-Asiatica ja dikundu} ku musoso ua ixi ia Ngola

Ku tendelesa Portugal se dingl alembalaia ia dikundile mu ki. usudi pala kulenguluka mu luso- zua kia 20 ia mbefl in Avril ia 1o, kubana o' Uene-Ngola ku kuà mwa ua 1961, mu-kukaiela ni ku ixi. O Assembleia Geral is O.N.U. ki $1603(\mathrm{X} \mathrm{V})$ :

ia zuba kudituna o ixinganeku ia Kla tatesa - kta kumu, kum Bulgara-Pulaco mu musoso ua ixi Portugat kamesena kukumbidila ia Ngola, o kibuka kioso kia 99 a llekelelu la O.N.U. i tu amhe Miji ia solo mba ia votala mu kià mu kuehela o Sub-Comissáo kukaicia ni kubanga o ixinganek's kubokona mua Ngola mu kuta. ni milonge a Afro-Asiatica, ku tela o kldi ni makutu ma kufua mbote ia ukexilu ni ufolo ua ana flpaxl, nzala ni kufua, kukata ni Ngola. IO Espanha kumoxt ni A- ungulungumba ua jipolutukefi us frica Do Sul) ene ngo aditunu mubanga kuhtandu d'ia ana ngoo ufolo ua ana Ngola, mu kuzole- la, mu kuxibaka mba kuxinuk. la mba kuvotalela ku mbandu ia mu kukumbidila o llekelelu ia klPortugal: o (França) muene ngo axind!

ka votalela ku mbandu ia Portu-

gal mba ka mbandu ia Ngola. Mu Tua talela ni dilamba mu kuikiki pe o ufolo ua ixi Ngola ua jiia kuma o Portugal hanji aji zukams kla.

Source: La Nation Angolaise (Kinshasa), 30-04-1962, p. 13

Central to the cross-border aspect of the Kassanje revolt is the role of a motley group of people called Suku. A critical examination of their reification helps illuminate the complex socio-spatial regional geographies that both resulted from and facilitated decades of movement and relations, and eventually enabled the cross-border anti-colonial mobilization. One group of Suku resided predominantly north of the Angola-Congo border, and another straddled the national border..$^{\mathbf{3 0}}$ Both groups traced their lineage back to the old Seventeenth Century Congo Kingdom to the west (the «Musucu» were mentioned in a February 1535 letter by King Alfonso of the Congo to the Pope). The southern Suku came to be governed by a

30 On the border formation, see Vellut (2006). 
queen (called the Ngudi a Nkama), following the military victory in the 18th Century over Lunda groups to the east by the sister of the king of the northern Suku. ${ }^{31}$ The subsequent descendent 8th Queen of the southern Suku, newly crowned in 1958 for being less fearful, is repeatedly mentioned in the 1961 colonial reports as identified by Angolans as a key agitator of the Kassanje revolt. ${ }^{32}$

Figure 5. Kabete, the sixth Ngudi a Nkama of the Suku (top two); a later Ngudi a Nkama; and the contemporary Ngudi a Nkama, Henriqueta Maria Mpangu
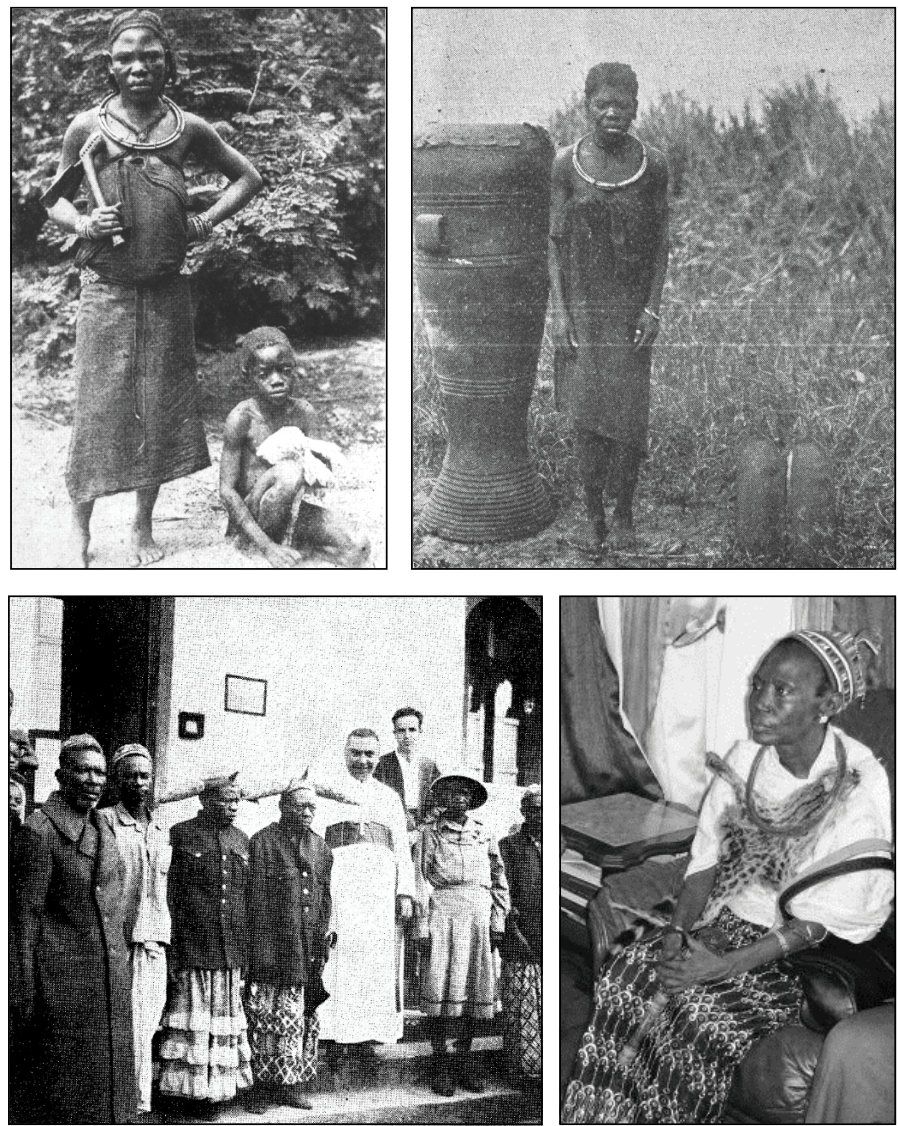

Sources: Cancela (1922a: 126), Mouta (1934: 211); Gabriel (1982: 241); JA (2012)

${ }^{31}$ See esp. Lamal (1965), and also Thissen (1965); Redinha (1971b), see also Bourgeois (1985).

32 The eighth Queen, Kamwangu, was invested in 1958, replacing her cousin, Kanadi, who reportedly was «eliminated» for being too «fearful» [craintive] (LAMAL 1965: 73). See Martins, M. (1961) «Apontamento 34: Incidentes da Baixa de Cassange (II)», March 7, p. 38, AHU. 
In various colonial reports on the revolt, Angolans were said to have associated Nguri a Nkama with «Maria», a name she was reportedly baptized with at the old Catholic Mussuco mission at Luremo after returning from newly independent Congo. ${ }^{33}$ Angolans near the initial unrest at Milando as early as January 13th mention Maria in Kasule Kwenda (some $70 \mathrm{~km}$ to their south east), suggesting that by then the Ngudi a Nkama had been there, possibly traveling through Kulashingo (Kulaxingu), across the sparsely inhabited forested hills and then to the east of the Kwango River. Indeed, at the Kwango town, near Kasule Kwenda, by February $5^{\text {th }}$ and 6th there was mention of an agitator from the Congo, and Angolans at Kwango also refused to plant cotton, while some 600 Angolans thereabouts had by then abandoned their work at the nearby burgeoning diamond operations on the Kwango River. Understanding the gendered roles of the Suku in trans-border trans-ethnic nationalist mobilization is thus key. ${ }^{\mathbf{3 4}}$

The important role of Suku also must be understood in relation to the complex shifting ethnic makeup of the region. The major ethnic group singled out by the Portuguese and Cotonang as agitators of the Kassanje revolt was actually the Holo, who trace their lineage not to the Congo kingdom to the east, but rather to the Kimbundu-speaking

33 There was also perhaps an elision of Ngudi a, Nguri a, Muria, and Maria (one report by a long-time officer in the area writes, «Múria-cama»). See Teixeira, op. cit. Other names mentioned are Maria do Cassuloquenda and Maria de N'Guriakama (Informação 262, p. 3). Freudenthal (1999) mentions some of this, but doesn't engage the important work by Lamal.

34 Such dynamics also shed light on the real limitations of the approach of Kopytoff, who conducted his dissertation fieldwork on lineage and religion amongst the northern Suku. Informação 145, February 6th 1961 (AHU); Informação 765, reproduction of Apontamento by Jose Torres Palma, Catholic mission at Mussuco. «Movimento religioso-político na margem esquerda do Cuango, Posto de Milando», January 1961. See also the sources in Freudenthal (1999). Further research is needed on the relevance to the revolt's gendered discourses and organization of the gendered and domestic education at the Mussuco mission (where girls began schooling in 1921, and nuns arrived in 1926). Schmidt's (2005) work on gender and popular nationalist mobilization in Guinea also has insights for and important connections with Kassanje. The PSA that was so influential to Kassanje was shaped by an encounter in Guinea between PSA leader Antoine Gizenga and his future wife, Andrée Blouin, an energetic and cosmopolitan woman from the Cuilo area, and also an "accomplished orator» who spoke the local language. Blouin was in Guinea in the late 1950s and «strongly identified with the independence struggle» there, returning to the Kinshasa hinterlands in March 1960 to found PSA's women's wing, shortly before the Nguri a Nkama arrived in the Congo (WEIss 1967: 177-178). 
groups to the south. ${ }^{35}$ Yet despite persistent colonial efforts at ethnic codification and mapping in order to facilitate forced labor, both Suku and Holo, however, have generatively combined, merged and differentiated various linguistic, cultural and socio-political aspects from broader Kimbundu- and Kikongo-speaking social groups (See also Vellut 1972, 2006; Vieira-Martinez 2006; Atkins 1955). There are, moreover, other related smaller groups, such as Kadi, Paka, Koxi, as well as larger bordering Ngola, Jinga, Xinji, and Lunda. Over a dozen different maps since the late Nineteenth Century show these groups in overlapping and/or shifting areas or zones, including both neighboring villages and ethnically mixed villages (Carvalho 1890: 118; Valle and Castro 1908; Diniz 1918; CanCELA 1922b: 126; JMGiC 1948; ViCente 1959; Thissen 1960; Denis 1962; NicolaÏ 1963; LAMAL 1965: 68; SAlazar 1968; Milheiros 1967; CARDoso 1970; Redinha 1971a). ${ }^{36}$ And colonial reports on the revolt clearly mention the adherence also to the revolt of the most prestigious chiefdoms of Jingas, Bondos and Bangalas. ${ }^{37}$ This stands in stark contrast to now crude-looking portrayals by some commentators, scholars or analysts that map the liberation movement parties MPLA and UPA/FNLA onto discrete, fixed ethnic blocs of «the Kimbundu» or «the Bakongo». ${ }^{\mathbf{8}}$

Part of the explanation why some of scholars cited above did not recognize such support and connections between different ethnic groups, and emphasized the lack of support and connections, was

35 See also Vicente "A situação actual da zona da "Tribu Holo"», do sector de Cunda Ria Baza e dos Postos de Milando e Tembo Aluma, AHU, 01/30/61, and Cann (2015: 53-54).

${ }^{36}$ See also the c.1961 map of Holos, Gingas, Bondos, Bangalas, and Songos in AHU c. p. 194 ; p. 12 of (1970) «Elementos sobre a etnia Jinga da Baixa de Cassange», PT/TT/scCIA/007/Oo05. Diniz (1918: 187) states that Mussuco region is «limited in the north by the Utungila River [...] and to the West by the Kuango River», but other maps put Mussuco on both sides of the Kwango, as well as putting Holo extending East of the Kwango.

37 Carvalho, J. (1961) «Situação na Baixa de Cassange», Letter to AdministradorDelgado, February 17 (AHU). Marcum (1969: 126) paraphrases Neto's (1966) mention of the significant arrest in March of Kulashingo (Kulaxingu), the King of the Bangalas.

38 The history of ethnogenesis in Angola still remains to be told, but a key part has to do with the efforts at taxation and labor recruitment by Diniz, and then «scientific occupation» by the Junta de Investigação do Ultramar and the Instituto de Investigação Científica de Angola, cataloguing ethnic groups, and hence the resulting static map of neat bounded ethnic units merits scrutiny rather than casual invocation (see DEGrassi 2015). 
because that was how colonial Portuguese propaganda deliberately sought to obfuscate the revolt in the tense context of the Cold War, United Nations hearings and national independence movements. In particular, Angola's Governor General wrote to the Overseas Minister's Office on March 9th that the Kassanje revolt «could be presented as a fight between tribes for external influence in which the Army intervened to defend the injured and peaceful», and Lisbon swiftly drafted a press statement to such effect, which was then repeated in major international newspapers. ${ }^{39}$

In contrast, at work behind the actual shifting, layered mix of relations between people that facilitated trans-national political mobilization were a series of longer-standing social, economic, cultural and political processes. ${ }^{40}$ The area's dynamics took shape in particular as a key slaving hinterland from the Seventeenth through the Nineteenth Centuries, using control over the Kwango River, and with the Holo also controlling salt pans on the Lui River (See LAMAL 1965: 70). ${ }^{41}$ However, at the end of the Nineteenth Century, as the Portuguese sought to establish «effective occupation» following the Berlin Conference, it was with the Suku queen Ngudi a Nkama that state-sanctioned missionaries established relations (THISSEN 1960). There followed booming rubber trade until the market collapsed around 1909 and then large-scale (but by no means complete) migration and displacement related to colonial military campaigns of occupation that sought to establish political-administrative control in order to allow a census of the population that would facilitate collection of taxes and mobilization of labor for infrastructure and

39 On March 11th the New York Times reported, «A Ministry statement said the "inter-tribal" fights broke out last month in the Malange district [...]», «Lisbon Reports Disorders", p. 2.

40 These processes are largely excluded from the static structural-functionalist approach that Kopytoff (1987) deployed. Indeed, Kopytoff's (1960) thesis, reliant on close collaboration with colonial authorities, only includes a single footnote noting famines in the late 1930 s and early 1940 s due to obligatory labor (p. 52). Cf. Holeman (1954). Likewise, Kopytoff's (1965) subsequent profile of the Suku devotes a few pages to colonialism and change, but mostly to dismiss the effects of migrant labor on the structure of the local economy and society.

${ }^{41}$ Holo were able to break off from the southern Kassanje formations in the late Seventeenth Century in order to control Kwango river crossings, and grew powerful from 1730 s to the 1760 s by diverting early slave trade from the east southwards, as well as mediating trade for French goods through the Congo port until trade shifted back southwards to Luanda as the French became pre-occupied with the Napoleonic wars (MILLER 1988). 
construction projects and agricultural production, which are discussed more in the next sub-section. ${ }^{42}$ What is key in all this is that rather than migration constituting an «exit option» to some other comparable abstract unit of land (à la Kopytoff), migration instead entailed a shifting relationship to both fixed resources and sets of social relations, and this would eventually facilitate anti-colonial organizing and the Kassanje revolt. ${ }^{43}$

Figure 6. Kabongo, the Holo
Queen «Holo diya Mukhetu»

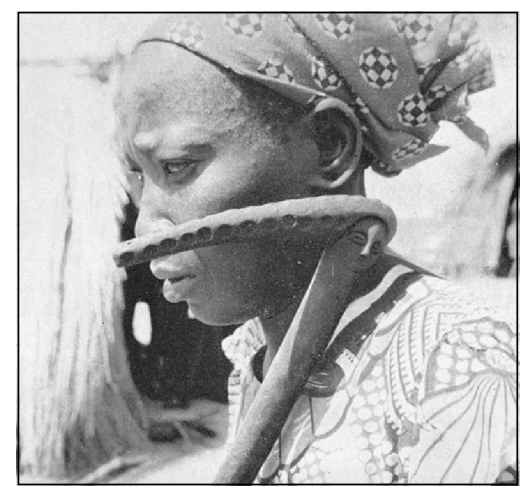

Source: Maesen (1956: 6)
Figure 7. Salt Flats at Kiongwa River, South of Kizenga \& Milando, $10 \mathrm{~km}$ East of Lui River

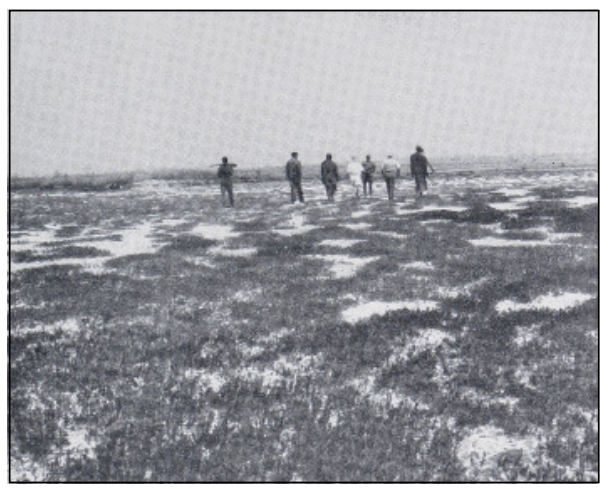

Source: Gouveia (1956: 165)

The turbulence of colonial conquest also was interpreted metaphysically with specific ritual practices that would be resuscitated during the 1961 revolt. ${ }^{44}$ The Kifumbi figure, for example, is reported

${ }^{42}$ See Pélissier (1986) on the military campaigns. See von Oppen (1993), and Cancela (1923), and Osório Junior, Vaz (1921) «Relatório da coluna de operações a "Uamba até Tembo Aluma», Arquivo Histórico Militar (AHM) 2/2/59/40.tituto de Investigação Científica de Angola, cataloguing ethnic groups, and hence the resulting static map of neat bounded ethnic units merits scrutiny rather than casual invocation (see DEGRASSI 2015).

43 Also worth noting is that careful research by Cameroonian scholars has shown that there was actually also significant ongoing peasant unrest in Aghem Cameroon while Kopytoff was doing the fieldwork there that shaped his thesis on "exit» and «internal frontiers» in Africa, though he does not mention such protest and discounts the importance of African researchers (KоРYTOFF 1977, 1981, 1995; МВан 2009; КАН 2009).

44 Around Mussuco in 1915-1923, there was hunger due to a disease outbreak amongst livestock (CosTA 1970: 136), and something similar was reported in Holo areas (MAESEN 1956: 5). In 1916, in Mussuco there was a rumor of a 
in some Nineteenth Century accounts with ritual sacrifice of human hearts, but its meaning shifted closely in relation to the forced labor associated with colonial spatial-economic transformation. ${ }^{45}$ Kifumbi haunted the rural paths hidden in tall grasses and would capture people to use the oils of brains, in varying accounts, for the engines of the labor-intensive industries to which many people were forcibly rounded up and sent without return: railroads, sugar factories, diamond machinery, or plantation equipment (EsTEves 2008). The Kifumbi illustrate metaphysically some of the long-term and extensive transformations and responses that shaped the region and lead to the particular form of the revolt, rather than a simple reflex to the economic conditions of cotton work.

In contrast to the notion that the Baixa was simply delegated to management by a foreign company, there was increasingly intensive government presence during and after decades of Portuguese military-administrative occupation, and an associated history of protest against such presence, even in the far northern reaches along the Congo border. Government interest had included, for example, designating a Holo and Jinga district as early as the 1850s, national border demarcation in the $1890 \mathrm{~s}$, and then opening of military posts at Mussuco in 1898 and Tembo Aluma in 1903, followed by years of conquest campaigns (ANON 1903; AnON 1910; SARMENTO 1916; GaGo 1921; Osório Junior 1921; Milheiros 1972). Then came non-military activities - for example, taxation, labor recruitment, a study

strange person, Mafulu, that had come from the Congo and had only one eye, one arm, and one leg, and would appear in the rivers and order the sacrifice of white cattle, sheep and chickens; one would then drink a potion to suppress spells and give immortality to honest people (GABRIEL 1982: 160). The new livestock capture and trade patterns appear to have brought new diseases, which were interpreted in relation to the military campaigns and millenarian visions; these practices were then resuscitated in 1961 in different form. This appears to be related to the spread of Kimbanguism, and a Mafulu revolt in 1918. Mafulu was also a term for a missionary. In 1928 in Sanza Pombo and Damba, there were similar notions of the apparition of a (white) person Mafulu from the river waters and killing of white livestock were present in revolts in Damba and Sanza Pombo (Santos 1972: 307).

45 The spelling varies: kifumbe, quifumbe, quifombo, kifumbi, etc. Thissen (1960: 170) interestingly discusses mumbi as a sort of «semi-material» spirit, spelling it also as nzumbi, which in turn perhaps parses out to nzambi and the more well-known English zombie. Esteves (2008: 112) also notes versions in Kikongo (kifumba), Umbundu (katokhõla), chokwe (thalyanga). However, Ribas (1969: 307) gives the root as kufumba (to damage), and describes it as a rural brigand or highwayman (bandoleiro) who would decapitate people. 
expedition in 1925, plans for a train line, inventories of peasant holdings, phytosanitary measures against locusts, etc. (See DinIz 1929; Alberto 1928). ${ }^{46}$

This growing government presence operated in increasingly close collaboration with Cotonang - detailed in section 5 below - to such an extent that the many of the practices of revolt were explicitly addressed not simply at cotton company practices but also at administrative measures. For example, although a compulsory national census (with stiff fines for non-compliance) was supposed to be carried out in January of 1961 (preparatory surveys had already covered the country), at that time the Queen Ngudi a Nkama sought to substitute for this authoritative colonial practice of censusing by ordering people to not obey, and to instead gather and be counted for her (presumably for propaganda and enlistment in the revolt) (PALMA op. cit.). ${ }^{47}$ This continued decades of revolts, passive resistance and migration against censusing for tax and labor ever since military occupation in the early $1900 \mathrm{~s}-1920 .^{48}$ It was only fitting that the 1960 Christmas Eve front page edition of the Malanje colonial elite's newspaper featured both the modernist questions «How Many Were We? How Many Are We?» and, a smaller type-faced article headline titled simply «Communism».

Similar processes were likewise unfolding unevenly across the border in the Belgian Congo (Denis 1962). By the 1930s these statecorporate exactions in parts of the Congo region had reached such an extent that they provoked a rebellion in areas with Pende, where some 500 people were killed by the Belgian army, and many others brought stories of the events as they subsequently crossed over to Angola where relatives lived (VANDERSTAETEn 2001). These processes also lead to migration from border areas of the Congo to urban centers such as Kinshasa and Matadi, as well as colonial projects

46 Bebiano, José Bacelar (1926) «Observações geológicas e apontamentos sobre a flora, fauna e etnologia da fronteira nordeste de Angola», Boletim Geral do Ultramar (BGU) 11, pp. 34-59. See also (1954) BGU n. ${ }^{\circ} 353-354$, p. 265; (1934) $B G U$ n. ${ }^{\circ} 103$; (1934) $B G U$ n. ${ }^{\circ} 122-123$, p. 123. One can also chart the detailed administrative presence in the number of papers in the archives (which do vary over the years), as well as the increase in the administrative divisions (see Figure 18).

47 See also DSEEg (1967), and Martins 1961, op. cit., p. 3, who also notes some people had gone to Taca to be censused by PSA.

48 See fn 84, Pélissier (1986), and various AHM and AHA reports; Vaz 1921, op. cit.; (1916) «Atentados CFL Ambaca» (AHM). 
and plantations, and sometimes to Angola also, where some labor contracts were more favorable, but there was also movement of farmers from the Angola to the Congo also. ${ }^{49}$ With the increasing commercialization of the countrysides (see sections below), the northern border town of Tembo Aluma became a commercial center in the 1950 for people from both Angola and Congo, with Portuguese merchants also trading goods from Kinshasa (DENIs 1962). These sorts of linkages would be critical to facilitating the PSA political mobilization when area youth then living in Kinshasa were forcibly returned home in 1959. The independence of the Congo was widely publicized and experienced in Malanje (and in the front pages of Luanda newspapers), not least given the significant numbers of white settlers and traders that fled into Angola, including some 500 to Malanje..$^{50}$ Tembo Aluma would be one of the earliest major areas of the Kassanje revolt, and Angolans in the area reportedly talked of "expelling the whites from their lands as was done to the whites in the Belgian Congo» (TEIXEIRA op. cit.).

Having painted some of the broad conditions of connection between Malanje and Congo, we can understand other organizers of the Kassanje revolt (drawing on Kamabaya [2007] and Marcum [1969]) through connections also to Luanda and the transformations in the cotton sector and broader economy and landscape of Malanje and Kassanje. In mid-1960, activists from Malanje and Luanda increasingly moved their operations to spend more time in the Congo, particularly following a the colonial police sweep in Luanda arresting 50 key activists and killing dozens of protesting villagers in the cotton town Catete outside of Luanda and reputed birthplace of Angola's first President Agostinho Neto.

A reportedly key organizer of the Kassanje revolt, António Mariano, remains largely unknown, but he apparently made trips back and forth from Malanje to the Congo. He was born in the suburbs of Malanje, just across from the neighborhood that had been transformed by the growth of the cotton industry with massive new

49 Vicente's (1959) internal Cotonang report notes that the area around Tembo Aluma saw 270 farmers flee in 1955, but then an increase of 455 farmers in 1956-1959 (AHU).

50 See coverage in the Malanje newspaper Angola Norte: (1960) «Os acontecimentos no Congo», July 16, p. 1; (1960) «Os refugiados do Congo Belga que passaram pela nossa Cidade», Aug 6; and see Mateus Ngola Katungo, in Freudenthal (2012: 19). 
Cotonang warehouses, processing facilities, and segregated white housing complexes. While Kamabaya (2007: 79) describes Mariano as a «Catholic catechist», there are also references to an António Diogo Mariano who worked for many years for the Protestant Methodist church in the Baixa de Kassanje, first in the south at Kambundi Katembo in the 1940s and then in the heart of the cotton lands at Kela in the $1950{ }^{.5}{ }^{51}$ Either way, Mariano both saw the deplorable conditions and organized clandestinely with other church members, with peasants, and sympathetic traditional authorities, in addition to underground nationalist political activists in Malanje and the Congo, fusing syncretically Christian, African, and nationalist iconography in the form of holy water, incense, and incantations to Maria and Lumumba..$^{\mathbf{5}}$ Working as driver in the cotton zone for an important Holo soba named Kizamba (in an apparently mixed Suku and Holo area where a Pastor Morton had installed a mission in 1929), he also drove his Chevrolet up on through to Kinshasa several times, and reportedly brought back UPA literature and nationalist ideas. ${ }^{53}$

Another activist born in Malanje, João César Correia («Makwiza»), had studied in the mid-1940s at the American Methodist college at Keswa, studied in Benguela, and, after meeting clandestinely in Luanda with inspectors from the International Labor Organization in 1959, also made the trek through the Baixa to the Congo in 1960, meeting along the way with Mariano and sobas, and returning in 1961 as a military commander of the revolt (KAMABAYA 2007:

$\mathbf{5 1}^{\mathbf{1}}$ There is also mention of an apparently different «António Mariano» joining the Methodist church around 1958 (Conferência Anual de Angola, p. 79). António Diogo Mariano was admitted for Methodist exam in 1942, and became an effective member in 1944, having become a pastor around 1953, and was also reported as working in Kalandula (Duque de Bragança) in 1960. He served on the Nominations and Inter-dominational Commissions of the Methodist church in 1959. See "Angola Conference General», 1959, United Methodist Church General Commission on Archives and History (GCAH) file 1459-1-4:2, and «Minutes of the Annual Conferences of the Methodist Church», 1944, p. 124; 1938: 28. See also Anuário do Ultramar Português, 1946: 117; 1951: 127; 1957: 130; 1959: 135 .

$5^{2}$ See also «Informação 216», February 27, p. 4 (AHU), which specifically describes «calcinhas» at Kunda dya Baze actively organizing people, also mentioned in Freudenthal (1999: 275).

53 Lamal (1965: 60) reports that the Kizamba sector «between Kwango-Lukunga» had 2,742 Baholo and 6.866 Basuku residents in 1959. See Marcum (1968:48), citing Neto (1966), a copy of which is yet to be located, but may be in the late Marcum's papers still awaiting processing at Stanford. 
106-107). Another activist, João Bernardo Domingos («Kyoza»), a cousin of Rosário Neto, spent more time Luanda, helping found the short-lived Movement for the National Independence of Angola around 1957. In order to avoid arrest by the secret police, he fled around 1960 to the Congo by passing through the clandestine political network of the Movement for National Liberation operating with the assistance of sympathetic Methodist priests in Keswa in Malanje. Shortly after the revolt Keswa would be called a center of subversion, having allegedly taught in geography lessons that "Angola is one of the independent African countries [...]» ${ }^{54} \mathrm{Kyoza}$ brought with him copies of a «Manifesto de Kasanji» for Rosário Neto. This Manifesto, authored by a ranged of nationalist figures in Malanje and Luanda, analyzed conditions in the Baixa, denounced forced labor, and argued for the total and complete independence of Angola, as in the Congo. ${ }^{55}$

\section{Malanje-Luanda connections}

Relations between Malanje and Luanda go back arguably half a millennia or more, so this section focuses just on a particularly important inter-linked set shaping the Kassanje revolt, specifically contracted labor, transport, landholdings, and church networks.

A key driver of Malanje-Luanda connections was the expansionary dynamic, in which taxation in cash and kind both was an objective to fund the state and a means for compelling labor for business, projects, services and a broader «civilizing mission». To help enforce tax collection and administrative rule generally, by $1936 \mathrm{Ma}-$ lanje alone was apportioned 313 cipaios across some several dozen

54 «Informação 696», March 29, 1961, p. 2 (AHU).

55 A range of other nationalist pamphlets, which made a point of emphasizing agrarian issues, had been printed, and circulated in Luanda, Malanje and elsewhere, particularly after activists with connections to Angolan sailors via the African Maritime Club in Lisbon were able to smuggle a lithograph machine aboard a ship to the southern Angolan port town of Lobito. Angolan and other nationalist organizers were able to use for their own purposes of political mobilization the changing transport and communications that were part of the exploitative agrarian and labor economy against which they protested. On the Clube Marítimo, see also Chase (2012: 102), Zau (2005), Rocha (1998), Linebaugh and Rediker (2001), Brown (2009). 
administrative posts. ${ }^{56}$ Taxation was a key subject of a great deal of attentive and varied colonial thought, design and action (often in response to the difficulties and contestation of implementing taxes) - by the early 1930s, there were already well over a 100 different legal measures issued on domestic taxation (not including issues of domestic and international trade tariffs and duties) (RAmos 1970). Given the experience of 19th Century tax revolts in Angola, the new 2oth Century legislation explicitly addressed in its start in 1906 the need for «smooth and progressive» «gradual extension» of taxation in order to "avoid resistance».57

State functionaries had a personal material incentive to boost tax collection, since they received percentages of the revenue as personal income bonuses, as well as a professional incentive, since the local government received $20 \%$ of the total, a practice that continued until 1961. This principle of «co-participation» also included small but significant percentages of tax revenue paid to participating sobas. ${ }^{\mathbf{8}}$

Consequently, by 1919, tax was collected from 500,000 eligible people out of Angola's total population of a couple million. By 1920, the hut tax had been converted to an individual «head» tax (by 1923, applied to men only), and an «exact» census in 1926 covered almost the entire country and population (and the remainder «inexactly»). Colonial state functionaries did quickly recognize that heavy taxes could prompt peasant resistance and avoidance, and hence taxes were varied and modified, harsh penalties levied, penal institutions established, numerous intermediaries of rule used, pass systems established, and roads constructed and villages resettled to enable monitoring and enforcement (where there was resistance to administrative orders, Angolan soldiers or staff could be shifted using the improved transport).

${ }^{56} 1934$ legislation provided for 172 cipaios in Malanje (Diploma Legislativo 603). The number was reportedly raised subsequently, but the 1958 legislation stated Malanje has only 239. The number of cipaios in Malanje was raised in 1937, 1941, 1950, 1951 and 1958 (see Portarias 1922, 2223, 3711, 7266, 7613 and 10275 respectively). See also Ordem Geral n8, Ordem de Malange n1, January 20, 1936.

57 See e.g. Decreto of September 13, 1906.

${ }^{58}$ Ibid., Portaria 375 of 1913, Portaria 11066 of 1959, Decreto 22793 of 1933, Decreto 23417 of 1934, and Portaria 2482 of 1937. 
What is also crucial to remember is that in addition to such explicit formal taxation, there was also a very significant effective taxation in kind through forced labor, which is harder to quantify but hugely important to peoples' daily lives, grievances, and colonial rule. Some of the extent of unrecorded local forced labor for transport infrastructure construction is discussed below in section 4.2 below.

Figure 8. Indigenous taxation in Malanje: Numbers (lft, columns) and value (rt, shaded)

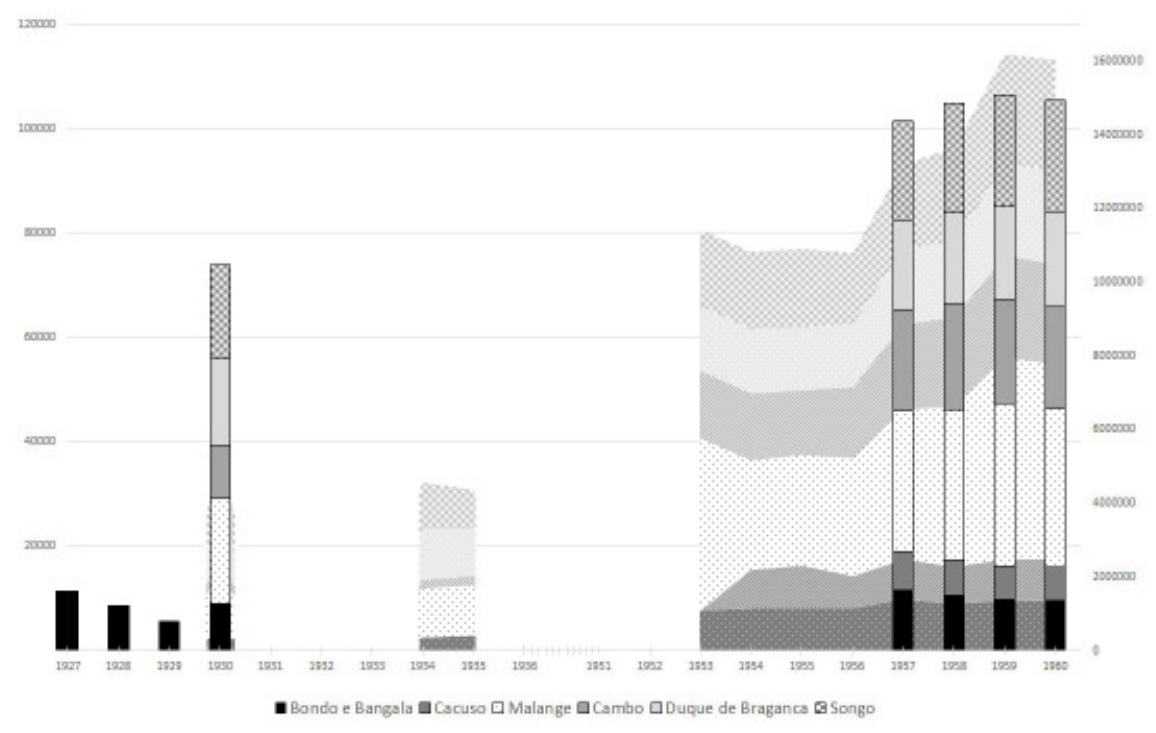

Source: Banco de Angola (1954-1960), GPM (1935), Dip. Leg. 242/1931

\subsection{Contracted labor}

Contracted labor was a key aspect of the Malanje economy, and connected people from diverse areas of the province, rural and urban, and connected people from Malanje with other places and peoples. Surprisingly, the extensive social relations of widespread contracting of labor throughout Angola have received little detailed scholarly analysis. ${ }^{59}$

59 Although the great historical importance of Angolan laborers has been widely recognized, and numerous studies discuss or mention slavery, forced labor, and contracted labor (Vos 2014), nonetheless few studies have actually looked 
Recruitment from the central highlands going to the northern coffee lands was the most important pattern of labor contracting, and that which is often mentioned. However, no in-depth study of that regime has been conducted, as far as I know. Moreover, no study has examined the significance of the patterns of the massive amount of other labor contracting. In 1958, for example, about twothirds of the total contract labor in Angola was from areas outside the southern highlands of Huambo, Benguela, and Bie that fed the coffee plantations in the north. ${ }^{60}$ Earlier statistics show from 1948 show Malanje supplying a quarter of the total contractees

\section{Figure 9. Road construction, contracted labor, and urban construction, 1911-1960}

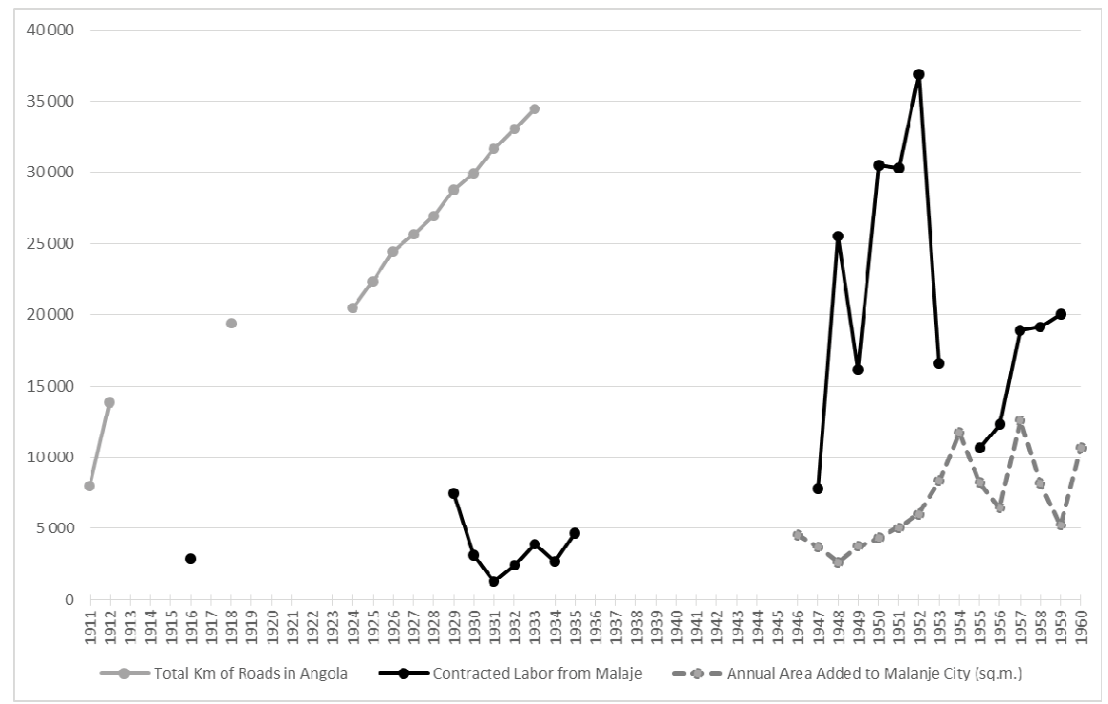

Sources: Anuário Estatístico; Diniz (1917, 1929); Mouta (1934) ${ }^{\mathbf{6 1}}$

systematically at detailed empirical evidence of labor contracting to understand the patterns of this labor, which is crucial in understanding the structure of the economy and the formation of socio-spatial relations throughout Angola. For example, the very interesting social history studies on contract labor to particular sugar and diamond complexes by Ball (2003) and Cleaveland (2008) provide many insights based on archival and interview data, but neither situates these in relation to the broader trends of contracted labor. Messiant (1983) describes totals and different types of labor, but what of regional patterns?

${ }^{60}$ One could compare the number of contractees given the population in the respective areas (particularly the population of working-age men), but it is also not clear that workers were in their villages of origin when the census was conducted. The census did include some numbers migrants living in other areas.

${ }^{61}$ It is not clear to what extent contract labor from Diamang in Lunda is also 
A small sample of records from 1952 quickly reveals that Malanje laborers came from a range of places throughout the province, and went to hundreds of different locations throughout Malanje, with hundreds of people also sent to areas further afield such as the coffee hills of Dembos, the Tentativa sugar plantation at Caxito, the outskirts of Luanda at Kifangondo, and so on. Contract labor, in short, was hardly restricted to use on only a few resource-intensive «enclaves», and instead connected a range of people, ideas and experiences - networks out of which the revolt would emerge.

The pool of possible contract labor in Malanje was reduced by Cotonang's monopsony since 1930 on recruiting labor in the cotton areas, stirring controversy, or at least that was the sentiment felt in internal Cotonang reports. ${ }^{62}$ There was competition over labor, colored though with variations of elitist and/or white nationalist business' critiques of foreign businesses. Exposés and reports at the time mention the extensive use of contracted labor, and there was an elaboration of various administrative bureaucracies for managing this labor. The state Agência da Curadoria monitored labor. Licenses were given to labor contractors. Wages and conditions were regulated. Identity cards for taxation and control of movement were designed, distributed, monitored and enforced. But the administration of these contracts also appears to have been rife with patronage, as fees were paid by contractors to government officials regulating contracting (See FERREIRA 1948: 4-5). So, it was not simply the harsh economic exactions that were felt and resentment, but

included in the category «Malanje» also, since the contract monitoring agency may have grouped them together administratively. The difference in the totals between years 1956 and 1957 is related to the classification and counting of contract laborers. Whereas in 1956 the classification distinguished between those contracted with and without intervention (of the state?), with $3 / 4$ of total involving intervention, for 1957 the classification was changed to distinguish between those with and without contract (and for those with contracts, whether for public or private purposes), and the new category of estimated non-contracted laborers was large.

62 The monopsony on recruiting labor in Kassanje was established with the Cotton Intendency, by Diploma Legislativo 242 on 13 January1930. It was reiterated in subsequent legislation, e.g. the 1946 Decreto 35844 Art. 54, which prohibited recruiting labor for work outside the cotton zone. On the contentiousness of this monopoly amidst labor shortage, see Ferreira (1948) and Banco de Angola (1956), «Relatório Anual da Agência do Banco de Angola em Malange: Exercício de 1956», Banco Nacional de Angola Archives, Malanje. 
also the loss of freedom of movement and autonomy, as well as the arbitrary depredations by the expanding bureaucracy. Some revolters put their passbooks, annual tax forms, and other cards on spikes (Informação 262, op. cit., p. 5). People did nonetheless try to use such forced labor movement to their own ends of sharing information and political conscientization. ${ }^{63}$ Repeated encounters with other laborers and residents from across Malanje and Angola helped forge a sense of a broader collective identity and struggle.

\subsection{Transport: Road and rail construction and use}

Laboring on transport infrastructure in particular was both a grievance as well as a means for political mobilization and revolt. Grievances about work were directly about the exactions, but also indirectly about how such infrastructure fostered further expropriations, injustices and risks associated with intensifying commercialization and extension of the state. Such grievances were also highly gendered, since women were disproportionately utilized, and yet saw men and the state attempt to restrict their movement, morals and money. However, the emerging transport system was also used by people to make social and political connections key to the revolt, and would also be sabotaged to try to prevent military repression.

Much of the early forced and contract labor went to constructing the Luanda-Malanje railway in the early 1900s, which was revamped in the 1930s, as well as a huge system of roads in the 1910 s and 1920s, which were also repaired and maintained through ongoing manual labor in the 1930s to the 1950s (Alves 1935; Ross 1925; DE Matos 1944; CGC 1939; SANTos 1927; Johnson 1929: 207). This investment of labor in turn allowed Portuguese administrative occupation and movement, and enabled the censusing, taxing, and mobilization of even more labor for other construction projects and for agricultural production. The rail, for example, was key to bringing heavy supplies and rations from Luanda for military expeditions to occupy Malanje and the diamond-rich Lunda Province in the North East from the 1900s through the 1920s (MACHAdo 1913; PÉLIssier

${ }^{63}$ See Freudenthal (2012); compare also Vos (2015: 115), and the work of Shana Melnysyn on the Bailundo Revolt. 
1986). Again, when the revolt broke out in Malanje in 1961, the railroad was used to quickly bring army units to Malanje.

Since the start of de Matos' reign, a staggering 25,00o kilometers were reportedly constructed from 1912-1923. By 1927, Malanje Province itself was reported to have $2,200 \mathrm{~km}$ of motorable roads, and by 1935 also a «considerable extension» of paths, some 118 bridges, and 10 pontoons (Ferreira 1927: 29-30; Alves 1935: 19 \& Appendices). ${ }^{64}$ Various road boards and brigades continued work through the 1930 and 1940s, increasing after World War II by the public investment of the colonial development promotion plans.

Equally if not more important than the main formal railroad and highways was the extensive quotidian forced labor supervised by local colonial administrators in the construction and maintenance of $18,000 \mathrm{~km}$ of dirt roads and $29,000 \mathrm{~km}$ of paths. Forced labor for road construction was legally enshrined in a series of general administrative laws throughout the first decades of the Twentieth Century. Although absent from national statistics, local labor was used by local administrators for local roads whose construction and maintenance such functionaries were responsible as part of their overall administrative duties. ${ }^{\mathbf{6 5}}$ The burden of forced local road work increasingly fell disproportionately on women who remained in their villages, since men were away as migrant labor to pay their taxes, from which women were exempt after $1923{ }^{66}$ By 1973, Malanje was reported to have $4217 \mathrm{~km}$ of picadas, in addition to the $2200 \mathrm{~km}$ of state paved roads and $249 \mathrm{~km}$ district roads (CASTRO 1974). ${ }^{67}$

Because the huge contributions of such forced labor were not quantified with a monetary value and thereby included in official colonial financial statistics, this effectively gigantic «payment» of taxes

64 See also the 1918 map of roads and planned road construction, which shows the roads connecting the capitals of the districts and the frontiers: «Rede estradas da província de Angola: construídas, em construção e projectadas», 1:2,000,000, Luanda, 46x70 cm (Biblioteca Central da Marinha, Lisbon, 2-1113/547).

65 See Portaria 375 Art. $26 \S 5$ and §22, Art. 58§3, and Art 78, and the 1933 Overseas Administrative Reform Law Art. $53 \S 4$ and Art.70 \$3.

66 See Decreto 235, February 2, 1923.

67 Such work also entailed possibly thousands of manual rock breaking sites; by 1958 there were a dozen registered rock breaking facilities in Malanje (Anuário Estatístico). The rise of roads can also only be understood in terms of managed competition with and substitution for rail transport. 
through labor has been grossly ignored by analysts emphasizing the «gatekeeping» aspects of states in Africa and the limited administrative reach. Indeed, the actual extent - quantified or not - of forced labor was often deliberately hidden or obfuscated because of the ongoing international publicity, heated debate, and scandals surround the heinous and often illegal and/or informal abuses and conditions (See COOPER 1996 and HigGs 2012). Simply because such forced labor was not given a financial value by colonial administrations in their accounting books does not mean that such forced labor did not occur. Indeed it is impossible to understand the subsequent shift to mechanization and the contemporary emphasis on mechanization in construction and agriculture in Angola without really documenting and appreciating the extensive painful histories of such pervasive but unquantified forced labor.

The decades of labor abuses incurred in building and maintaining the roads generated widespread resentment. Some such abuses in Malanje were documented in a published report transmitted in June 1925 to the League of Nations' Slavery Commission about the continuing labor abuses in Portuguese Africa, in turn contributing to the League's passage in September 1926 of the Slavery Convention. The Report and Convention came after international outrage several decades earlier about forced labor from Angola being used on cocoa plantations in São Tomé - and which in turn spurred some minor changes as well as Angola's new labor code a few years later. Likewise, the Norwegian anthropologist Amandous Johnson had also traveled to Malanje around the same time, and documented similarly outrageous abuses of women laborers constructing roads leading east from Malanje city towards the Baixa:

«Early one morning I was awakened by mumbling sounds that seemed to come from a thousand voices [...] On the large open space in front of the station stood about 300 women in the damp cold with only a loin cloth, stiff with dirt on it. All had baskets on their heads and many a child on her back. Afterwards I found out that they had been ordered out to repair the roads. Approximately twenty of them stood separate from the others. After a few minutes a Negro soldier swung a whip. After having commanded the one who was lucky to hold out their hand, he gave out six or eight lashes on their palm. The women took against the beating without making a sound, shook from punishment on the hands, held them under their hipdress and stepped 
to the side, as if it were an everyday event occurring. But the kids, who did not understand it all, screamed mercilessly. The poor victims had probably sought to deceive the government on a few hours of work by staying at home or hiding in the woods, or maybe they were ill and unable to work» (JoHNSON 1929: 207).

An end result of such stark and widely resented and remembered abuses however was greater fixed capital in the form of roads that facilitated circulation of forced labor to plantations and other works. Transport facilitated such contracted labor, and hence also a growing commercial economy, which entailed the significant movement within Malanje and to other provinces, as illustrated by the traffic figures for the smaller train stations in the year 1960. From small towns that were not even municipal capitals, thousands of people rode the train. ${ }^{\mathbf{6 8}}$

Passenger traffic on trains was gradually facing competition by growing networks of bus services. The state allocated particular private companies with specific routes. ${ }^{69}$ In 1957, for example, there were 45 of these regular bus and trucking routes throughout nearly $10,000 \mathrm{~km}$ of the country. By the late 1950 os transport from Luanda eastward through Malanje picked up, particularly for the heavy machinery needed to power, process and support the increasingly mechanized diamond extraction that was spreading west from the dwindling initial alluvial finds towards the Kwango River on Baixa's eastern edge, where hundreds of diamond workers would join the revolt. ${ }^{70}$

Beyond the railroad terminus, the road network in the Baixa de Kassanje was improved partly through financing from cotton sales. Under a 1936 law, 2.5\% of the total amount that Cotonang paid in purchasing cotton from farmers was allocated to a special government fund for purposes of road building and conservation. So, while this could be interpreted as colonial delegation to a private

68 3,703 at Cambunze, 8,647 at Cacuso, 1,870 at Matete, 1,451 at Aldeia Formosa, 399 at Cacolo, 1,943 at Lombe, 1,542 at KM 417, 15,211 at Malange, for a total of 34,766 (BA 1962).

69 The routes were outlined in the Anuário Estatístico.

$7^{0}$ See «Informação n. ${ }^{\circ}$ 145/61-G.U.» 06/02/61, AHM; Anuário Estatístico 1957, p. 215; Cleaveland (2008); (1953) «Pontes na Província de Malange», Angola Norte, Dec 19, p. 1; (1956) «A Companhia de Diamantes de Angola», Angola Norte, Sept 8, p. 1. 
concessionaire of state functions of tax collection, in reality that was only a relatively small task, as the funds were still managed and spent by state authorities, who had to find and mobilize labor for the road works. The situation was one of increasing state-private collaboration, rather than any one-off delegation. The result, after ten years, was an extensive network of $865 \mathrm{~km}$ of roads in the cotton zones, which more than doubled in the next ten years to $1711 \mathrm{kms}^{71}$ By 1961 Kassanje peasants would protest these state exactions of labor for road works - not just cotton prices - and aim to turn the road network to their advantage militarily by setting up roadblocks and ambushes, destroying bridges, and refusing to obey state officials' orders (see also CANN 2015: 55).

\subsection{Rural and urban land and the settler economy}

Increasing economic, social and political discontent in colonial Malanje was shaped by the great extent of land claims, land inequality, and general «rural reordering» in Malanje and Angola before and after 1961, though these have been significantly underestimated by most analysts. These dynamics went well beyond the usually mentioned purported enclaves of cash and export crops, and the «strategic hamlets» in war zones.

In an important decades-long process beginning in the early Twentieth Century and variously called «villagization», «concentration», «regrouping», and «rural reordering» - which deplorably has yet to be studied thoroughly - thousands of rural villages throughout Angola were ordered by colonial administrators to be concentrated from dispersed locations near water sources and moved into dense linear settlements along ever more flat and straight roads. $^{72}$ The legal foundations for this were laid as early as 1911 in laws specifying reduced hut taxes for people living closer to municipal capitals, regional roads, and military posts, soon followed by orders for local administrators to force Angolans to live in «concentrated» settlements of no less than 10 structures, or face stiff fines.

\footnotetext{
${ }^{71}$ See Diploma Legislativo 859, Bо 47 of 1936 (this also modified Diploma Legislativo 242 of 1930, which used 5\%). See GDM (1954: 33).

${ }^{22}$ For further details and references on this section, see DeGrassi (2015).
} 
Chiefs were also given a financial incentive to concentrate villages since their stipends were based on village size. ${ }^{73}$

The great significance of these phenomena is that they connect the processes throughout Angola with what was happening in Kassanje (cotton concentrations), thereby reframing the Kassanje revolt away from an example of state neglect and delegation and instead as an example of the sort of state intervention that was in fact more pervasive throughout Angola than is commonly recognized.

Village concentration in practice facilitated clearing land for settler plantation claims in a more extensive area than the export crop zones that are usually emphasized (cotton, coffee, and sugar). Firsthand research in Malanje's colonial land archives showed that official land statistics about provisional and definitive concessions failed significantly to accurately show the actually much greater extent in practice of land claims and inequality. The land inequality in the agrarian economy combined with not only contract labor and various infrastructures, but also the economic, social and political dynamics of urban restructuring and trade. The nationalist networks and organizing that went on spanning Malanje, Congo and Luanda were informed and motivated by this broader pattern of growing segregation and inequality in the booming settler economy. The numbers of white Portuguese in Malanje city jumped, and white traders increasingly set up shop in smaller municipal capitals and towns. Much of the massive post-World War II urban restructuring of Luanda was driven by the booming coffee plantation economy, until the coffee price crises of the mid-late 1950s (PAIGE 1975), as demonstrated spatially by the landmark studies by Angolan-Portuguese geographer Ilídio de Amaral (1960, 1968).

The settler coffee boom-driven urban restructuring must have been apparent to the many subsequent elite in government and politics, such as Agostinho Neto, who attended the Liceu Salvador Correia in the quickly changing Ingombotas neighborhood (CORREIA 2009). Ingombotas was established much earlier from dislocations, and lowlevel informal housing remained after the train tracks were removed from its modest incline and shifted up the coast. By the coffee boom

731911 Regulamento, Art.110; see also Portarias 377 and 378 of 1912, Decreto 1224 of 1914; Portaria 137 of December 1921, as well as a piece of legislation in Boletim Oficial n. ${ }^{\circ} 12$ of 1913 . 
however, African residents in Ingombotas were being displaced by apartments for white settlers (AMARAL 1960, 1968).

Socio-spatial connections and political consciousness were also stoked by processes of urban restructuring underway in provincial capitals and smaller towns throughout Angola. A series of colonial city planning and urbanization plans and projects were undertaken. These built on, exacerbated, and entrenched the still visible segregated spatial structures in dozens of municipal capitals and small towns across the Malanje countryside. This quotidian segregation has received much less scholarly attention than Luanda, but was perhaps more pervasive.

During his year in Malanje in 1945, for example, Agostinho Neto, as he walked up the city's main road, passed by visible buildings embodying this new order. ${ }^{74}$ He passed the bustling trading stores, the car and agriculture suppliers, the end of the train line, with its hulking Cotonang warehouses, and, as he reaching his work at the medical office, he would have seen the construction work on Cotonang's new segregated residential neighborhood nearby. ${ }^{75}$ It was in the burgeoning forced-labor cotton-plantation hub city of Malanje that he is reported to have experienced life-altering racial discrimination when he was refused entrance by a low-tier hotel for whites only. Ten years later, Amílcar Cabral, too, after meeting with Neto in Lisbon, would walk these streets past Cotonang on his way up to do research tests at silos quickly filling with plantation settlers' maize crop from that season's first harvest. From Cabral's impressions and the statistics from his agronomic research in Malanje and elsewhere in Angola, he would several years later in 1960 pen his polemic The facts about Portugal's African Colonies, decrying humiliating segregation, land expropriation, and forced labor in cotton and coffee in Angola, noting how some of such agricultural wealth ended up in ownership of «blocks of flats in Lisbon» (CABral and Fonseca 1956; ViCENTE 2011: 55; IICT and INEP 1988; CABral 1980). ${ }^{76}$

\footnotetext{
${ }^{74}$ See also the colonial urban development plans for Duque de Bragança (Kalandula) and Malanje.

75 See (1948) Angola Norte, May 29; (1958) Angola Norte, Dec 6.

76 The presence of agrarian capital in urban buildings can also be gleaned for Malanje by some of the confiscations in Diário da República Despacho Conjunto 47-Y of August 28, 1992, such as those of A. Santos Pinto, SIPP, Vitorino Sampaio Magalhães, Evaristo Machado, Leonel Gomes Pinto, Fazenda de Santa Isabel, etc.
} 
In addition to being invested in real estate and construction, the profits from the expanding contract-labor based plantation economy also often circulated through usurious trading stores that sold imported goods on credit at high interest rates to farmers (SANTOS 2005). From 1954 to 1958 the number of registered trading stores in Malanje Province increased by a quarter from 362 to 448 (BANCO DE ANGola 1958).

\subsection{Church networks}

Catholic and Protestant Church networks linking Malanje and Luanda, and perhaps Congo, and numerous small towns were also key in the facilitating the revolt, through both education and connecting people from disparate areas. ${ }^{77}$ The Catholic churches in Malanje expanded from the city in 1890 to the Baixa in 1900 (Luremo/ Mussuco) and 1913 (Bangalas), with another two in the mid-193os, and four more by 1960 , some with close relations with Cotonang (See Polanah 1970; Ferreira 1942). These often involved schools, and a range of indigenous catechists - by 1959, across 13 parishes in Malanje there was a total of nearly 250 staff (Anuário Estatístico). In the Methodist church also, there were a range of different commissions, activities, and forums, involving the direct engagement of thousands of people across the Baixa. Rotating positions through the church exposed catechists to diverse and challenging circumstances and communities, and helped forge connections, foster debates and circulate ideas.

One particularly important figure was the Reverend Job Baltazar Diogo, who studied at the old American Methodist college in Keswa established in 1887 , but also served in the historic rocky town of Pungo Andongo amidst proliferating European plantations. ${ }^{78}$ During the

77 In the 1950s, the Methodist church in Malanje also had a presence in the southern Congo, including Kapanga, (with a hospital), Sandoa, the growing mining site of Kolwezi, Mulungwishi, Jadotville, and Kinshasa.

${ }^{78}$ See Kamabaya (2007), and also «Minutes of the Annual Conferences of the Methodist Episcopal Church», 1934, p. 415; Anuário do Império Colonial Português, 1946, p. 117. 
Figure 10. Reverend Job Baltazar Diogo in Keswa translating the bible into Kimbundu in 1960, before his arrest in 1961

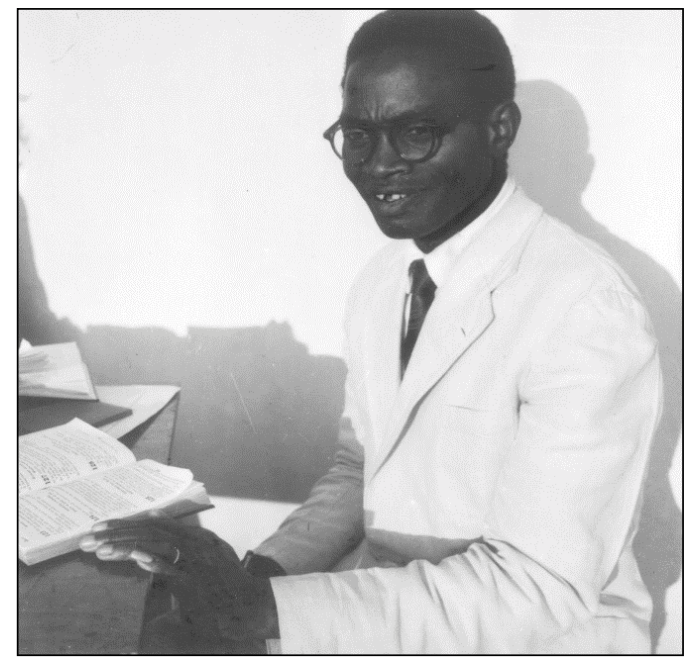

Source: GCAH File 2190-3-3:2

coffee boom years, he served in the rebellious Dembos coffee district, which saw massive land alienation for European plantations. ${ }^{79}$ Upon his return to Keswa, he worked on translating the bible into Kimbundu (working on II Kings, Ecclesiasticies, Genesis, and Exodus in 1959-1960), served on a range of church commissions (youth, music, memory, and ritual), and coordinated a clandestine cell of the National Liberation Movement at Keswa, as well as joining the UPA. Reverend Diogo's son, Bornito de Sousa, is now Minister of Territorial Administration, and presided over commemorations of the Kassanje revolt, together with Boaventura Cardoso. Cardoso was then governor of Malanje, and a former Minister of Culture, and was the son of the popular nurse, dentist and underground political activist Sebastião Cardoso, who was also active in Malanje at the time of the Kassanje revolt. Other major nationalist figures that were active in the church included Cónego Manuel Joaquim Mendes das Neves, who was born in the coffee areas west of Malanje,

79 Agostinho Neto, the mPLA leader and Angola's first president, also spent time in Piri in the plantation coffee lands of Dembos, and notably, its massive 48,000 ha concession of Jose and Eduardo Anapaz (Anapaz \& Irmão) in Piri, which was also the birth place of Nito Alves, an MPLA figure and leader of a repressed «protest»/ «coup» in 1977 (VICENTE 2011; GGA 1944). 
and was in contact with Diogo and a wide range of other nationalist and church figures, including Father Joaquim Pinto de Andrade. It was under Father Pinto de Andrade that Rosário Neto had studied at the Seminary in Luanda (Kamabaya 2003, 2007). ${ }^{\mathbf{8 0}}$

So, rather than view nationalist politics as restricted to a cosmopolitan coastal creole elite, with separate parochial peasant protests in exploited interior enclaves, the political mobilization in the larger Malanje region was part of a larger extensive history and geography of explicitly nationalist protest that connected issues of land and labor exploitation to demands on the colonial government and the international community for equal rights and independence. As illustrated above in relation to the Congo connections, people protested both in relation to experiences in the past and familiarity with other places, as well as their immediate concerns. Rosário Neto, for example, drew on the experiences of his grandfather Joaquim «Kanguya» Filipe Cardoso, who was jailed for trying to petition the League of Nations in 1927 for Angolan independence (as described for Jamaica by Marcus Garvey). Kanguya wrote as part of a broader "Nativist Movement» throughout parts of northern Angola since 1917 at least, which included various attacks and threatened bombings of the railway, with August 15th appointed as Angola's Independence Day. ${ }^{81}$ Earlier, in the 1910 s and 1920s, the famed writer António de Assis Júnior penned a diatribe against land expropriation in the coffee areas, and others such as Quimamuenho (Kimamwenyu) worked tirelessly defending peasants against dubious settler expropriation of their land (FERREIRA 1989; CORRADO 2008; Assis JÚNIOR 1917). And in the 1920s and 1930s, there were related syncretic Garveyist, Kimbanguist, Kasonzola and Jehova's Witness Watchtower/Kitawala activities ideas circulating around the region (Marcum 1969). ${ }^{\mathbf{8 2}}$ Likewise, Marcum (1969: 47) notes « $a$

80 See also the seminarians between Keswa and Cacuso later arrested, in «Informação 691", April 1, 1961 (AHU).

81 See Marcum (1969: 47), who says Cardoso was also known as «Canguia». Marcum reports that Kanguya's son (Rosário's father or uncle) also organized «Baha» protests and secret cells in the 1950s. See "Nota ao Quartel-General ao comandante militar do Dondo de 6-Abril-1918 transcrevendo uma carta que dá conta da situação actual do cabecilha da revolta João Caiangue» (AHM 2/2/51/12), and «Auto de declarações de Manuel Velasco de Beça Teixeira prestadas em Pungo Andongo sobre o Movimento Nativista», 1917 (AHM).

82 On Black Moses in Quela (Kela) in 1924, see Santos, cited by Pélissier (1978). 
movement known as Moïse Noir [Black Moses] spread through the countryside. According to its message, American Negroes would come to liberate the African from European oppression». Six years prior to the 1961 revolt, there were reports around Tembo Aluma, Milando and Ginga posts of renewed religious «Kasonzola» agitation similar to that underpinning the revolt, with killing of white livestock in expectation of a savior «who would descend the Cuango and bring arms, gunpowder and money so that the indigenous would have means to wage war to liberate themselves from whites». ${ }^{\mathbf{8}}$ And again, in June 1960, the time of Congo's Independence, there were still further reports of Kasonzola in Malanje. ${ }^{\mathbf{8 4}}$

The Portuguese colonial regime responded to such unrest with a mix of increasing administrative surveillance and policing, particularly through increasing the numbers of the several hundred cipaios then spread across the administrative posts of Malanje. ${ }^{\mathbf{8 5}}$ However, there were also token efforts at providing social measures in some of the key and contentious areas, either directly or through church or charitable organizations, in the form of a commission on cotton prices, corporate and labor laws (weak and often unenforced) and social development schemes and projects (such as, water, education/ training, health, housing, etc) (e.g. CUNHA 1953; CRCCAU 1961). ${ }^{\mathbf{8 6}}$ So, rather than view the Kassanje revolt as spastic reaction against dropping prices in a purported delegation by the state to a privately run enclave, instead the revolt grew out of broader and longer-term expansion of contested negotiations between different social groups and state and corporate agents.

In sum, there were multiple, overlapping networks of people connecting the regions of Malanje and Luanda through different sorts of relations - through churches, contract labor, commerce, migration, and activism. The links were not simply arcs between

83 See Martins, M. (1961) «Apontamento 14: Os Incidentes da Baixa de Cassange», January 30, p. 14, AHU. On Kasonzola more generally, see Pélissier (1978).

84 Arcaute and Asúa (1961: 49) mention reports around northern Malanje of a «Casonsola Mission».

85 See fn 55, and AHM reports: da Silva, Major José Inácio (1915) «Inspecção 9. ${ }^{\text {a }}$ Companhia Indígena de Infantaria - Malanje»; Vieira, A. (1939) «6. ${ }^{\text {a Compa- }}$ nhia Indígena de Caçadores»; Rodrigues, J. (1937) «Instrução de Recrutas do

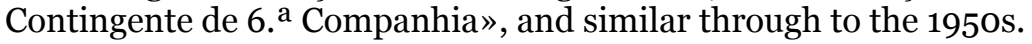

86 See Neto, J. (1960) «Algumas considerações acerca da Zona Algodoeira da Baixa do Cassange», Delegação de Quela, JEA, November 29. The cotton price commission was ordered in September 1, 1960, in Oficio 15/60. 
the two main cities, but involved dozens of small towns, villages, plantations, mines, projects, factories, homes, churches, stores, and other sites. These places carried their own sedimented histories of connections, transformations and protests, and it is through these layers of relations that the 1961 revolt emerged. What was also key, however, was not simply Malanje's role as a crossroads, with connections to Luanda and Congo, but major socio-spatial transformations in Malanje and the Baixa de Kassanje region itself, some of which have already been mentioned.

\section{Transformations in Malanje and Kassanje}

In addition to the important roles of connections through to the Congo and Luanda, the precise timing of the revolt should also be understood in relation to the particular conjuncture of circumstances in Malanje. The prior year had seen heavy rains destroy crops, the head tax rate rose $15 \%$ in 1959 , and costs of living and particularly food prices had risen in Malanje Province since $1957 .{ }^{87}$ The late 1950 s saw declining numbers of people growing cotton due to mounting difficulties with intensive cotton production, including increased pest and weed problems, concentration of farms distant from peoples' villages, and heavy investments in lowland drainage and soil conservation and erosion works. ${ }^{\mathbf{8 8}}$ State and Cotonang reports had complained for years about the lack of labor due to natives' primitive and lazy nature, and also problems of inadequate food production in the area. In response, and contradicting notions

87 On the impact of the rains on production, see figures in Figure 1. Price indexes are in the Banco de Angola reports for Malanje, it is not yet clear what the cause of the increase was. On poor rain, see Cotonang (1961) Relatório e Contas 1960, Cotonang, and Angola Norte 6 June 1960 and 24 December 1960. See Banco de Angola on the tax.

88 In particular, the weed imperata cylindrica, known locally as senu or seno, and pests such as lygus, diparopsis, heliothis, jassids, and dysdercus (NunEs 1960; Dias dos Santos 1960: 8; Cotonang 1960a, 196ob; Georges 1960; Gouveia; Salazar 1968: vol. 1, pp. 30-31, 2; vol. 2 p. 10; MacDonald 2004). A pest Disinfestation Program approved by the Governor General planned to treat 7,000 ha in 1961, increasing to 31,000 ha by 1963 (Administrador Delegado, Cotonang Relatório 1960 «Esboço de um programa de desinsectisação da cultura algodoeira na Baixa de Cassange» July 12, Lisbon, 16pp.). 
of a private enclave, in these projects, state officials from the Cotton Export Board (Junta de Exportação de Algodão) worked closely with Cotonang employees (there were roughly 400 Cotonang agents by the late 1950s) to concentrate tens of thousands of farmers in lowland areas where they could be monitored and forced to work the heavy dark soils that were fertile but also susceptible to flooding. Moreover, local state administrators received bonuses based on cotton production levels and not only helped enforce these measures but also illegally prevented many Angolans from leaving to seek work elsewhere (Cotonang 196ob; Dias dos SANTos 1961: 13; JEA 1960: 4) ${ }^{89}$ Under a 1949 law, everyone in the cotton zone was required to show proof of cultivation through a special green-colored cotton passbook («caderneta»), which showed how much they had produced and sold, where, when, and with how much seed. ${ }^{\mathbf{9}}$ In a stinging report written shortly after the revolt, the Director in Angola of the state Cotton Export Board could not have been clearer in blaming local state agents rather than just Cotonang employees: «the cause that contributes most to the poor condition of people in the cotton zones» was «too intense intervention by the administrative authorities» (DIAS DOS SANTOS 1961:4). The scholars mentioned above got it wrong in emphasizing delegation to a private company enclave and economic protest against only poor prices - state intervention in the cotton concession areas was prevalent, intensive, and insidious, illustrated powerfully by the issue of field and settlement concentration.

Colonial administrators were rhetorically attentive to potential conflicts between the forced cotton production calendar and food crop production, but in practice there were several issues and times when there was conflict. The work rhythm was spelled out in detail.

89 1960, Cotonang, and Angola Norte 6 June 1960 and 24 December 1960. See Banco de Angola on the tax.

90 See Portaria 6919 of 1949. 
Figure 11. Cotton production and marketing calendar

\begin{tabular}{l|l|l}
\hline Date & Activity & Days \\
\hline Early December & Seed Distribution & 1 \\
\hline Mid December & Preparation of Land & 15 \\
\hline Start of January & Sowing & 6 \\
\hline Mid-January & Re-sowing & 3 \\
\hline Late January & First weeding & 8 \\
\hline Late February & Second weeding & 8 \\
\hline Late March & Third weeding & 8 \\
\hline Early June & Construction of drying racks & 3 \\
\hline Mid June & First Harvest & $\mathbf{1 1}$ \\
\hline Early July & First Market Sales & 6 \\
\hline Late July & Second Harvest & $\mathbf{1 1}$ \\
\hline Late August & Second market sales & 4 \\
\hline Early September & Third harvest & 4 \\
\hline Early October & Third market sales & $\mathbf{1}$ \\
\hline Mid October & Pulling up and burning & 2 \\
\hline & TOTAL: & $\mathbf{8 9}$ \\
\hline
\end{tabular}

Source: Dias dos Santos (1960: 8) ${ }^{91}$

There are two rainy seasons for growing crops, one from roughly late September to December and one from late January to April. Cotton was cultivated from December to May. The difficult male labor of preparing fields in December falls precisely at the end of the major hungry season, in which the stored food reserves have been exhausted, but the crops planted in September and October have yet to yield. In that context, farmers are required to perform heavy labor, and also to spend a significant proportion of the money earned in cotton sales in July and August on taxes. ${ }^{92}$ Another potential conflict had to do with the strict state-appointed time for sowing 100 in January and February, which could detract from time for food harvesting. ${ }^{93}$ At the end of the cotton season, some cotton weeding and harvesting would be done in the lean season long after important

91 See also João Vunje in Freudenthal (2012: 18), and fn 103.

92 Legislation set tax collection for the start of January (see, e.g., Portaria 3817 of October 22, 1941, though other early or later legislation may also state this).

93 See (1958) «Cultura do algodão no distrito de Malange», Angola Norte, March 5 . 
short-cycle food from the first growing season had been harvested (such as maize, peanuts, beans, tomatoes, squash, cabbage, and sweet potatoes, but not yam and cassava). Closely related to temporal conflicts between food and cotton production were spatial issues of designated cotton plots, distances from villages to such plots, and relocation of villages to concentrated cotton plots.

As mentioned in section 4.3 above, the concentration of cotton plots in the Baixa de Kassanje should be seen not as exceptional but rather as a clear manifestation of a processes that were occurring throughout much of Angola, namely state-directed village concentration, in conjunction with taxation, road construction and administrative control.

By 1960, most of the people growing cotton for Cotonang in the Baixa, some 31,000 people, were farming at 400 «concentrations» in 21 different «sectors» of the Baixa, with each sector's lands parceled into reserves based on presumed optimal aptitude for growing cotton. ${ }^{94}$ Concentration was said to facilitate technical productivity, and control over production, workers, and sales, all deemed necessary to address the accumulating problems of the preceding intensive years 1933-1943, namely increasing pests, soil fertility, disease, low production, and fleeing labor (Neves 1954: 12-15). ${ }^{95}$ As the commercial cotton agro-industrial economy boomed across the region, such changes in production and settlement occurred together with changing movements of people, goods, money and ideas.

Concentration in the Baixa in particular had been pursued as production increased and the colonial state's Cotton Export Board was created in 1938. A 1946 law tasked the Cotton Export Board with promoting concentration, which together with crop-rotation was promoted as a solution to scarcity and fleeing of labor, as well as lack of food crops. The state Cotton Export Board would delimit which areas within the overall concession zone were suitable and allowed for cotton growing, and Cotonang was obliged follow the Board in promoting concentration accordingly. ${ }^{\mathbf{9 6}}$ Efforts to concentrate production on

94 The total land reserved in such concentrations was 60,000 ha. See Cotonang 1960; Gouveia (1956).

95 Farmers had also to arduously carry cotton loads to the set markets whose location was established by state agents, apparently along the roads for Cotonang's convenience rather than close to lowland cotton fields (see [1953] «Produção algodoeira indígena», BGU 332: 137).

96 Decreto 35844 of 1946, Art.3; See also Isaacman (1996: 133-134). 
«appropriate» soils were further bolstered after an extensive soils survey was done in mid-1954 by a state agronomist with the help of state and Cotonang employees. Colonial prejudice prevented administrators from addressing how concentration to enforce foodcrop production would not resolve nutritional problems, and in fact could exacerbate them by increasing traveling times, land clearance and weeding labor, and susceptibility to flooding. For example, in the published official legislation, the Colonial Minister dismissed food scarcity in cotton zones as due to «the naturally lazy and fatalist psychology of bantu people».97

A fairly exhaustive household nutrition survey across the Baixa by the President of Angola's Provincial Nutrition Commission had found that "The separation between the villages and the fields for cultivation creates a modus vivendi on the part of the populations that results in a low nutritional level» (NuNES 1960: 399). However, the report did not criticize the problem of the state designating distant cotton areas, but instead proposed increasing the ongoing concentration of people near designated cotton plots. Such dislocation was simultaneously meaningful and material, as people were uprooted from their homes where they had ritually treated, or planted beneath milolo trees, their children's placentas so as to ensure their children's health and intelligence, which were in evident decline (See SAlazAr 1968, vol. 1: 153; vol. 2: 65). Reported instructions during the revolt spoke to the political importance of these specifically domestic aspects of grievances, requiring revolters to «be done with the grass houses» of the sort built as temporary encampments in the cotton concentrations, and consequently avoid the irritating cramped space and changed gendered division of labor in such temporary encampments: "[do] not have utensils and items in the bedroom but rather in the kitchen, another house, or outside», and "only women can cook» (PALMA op. cit.; Informação 216).

Spatial restructuring that forced planting in areas that would later be flooded caused resentment, which was an important proximate grievance of the revolt (DIAS DOS SANTOS 1961: 5-6). It was

97 Decreto 35844 of 1946 , §9c. 
distinctly not as simple as heavy rains alone prompting the revolt - rather, because of spatial restructuring of settlement and cultivation, there was a public-private production of vulnerability to rains. The cotton crop losses to flooding were not a fluke of nature.

The heavy rains in 1960 marked the return of a grievance about forced cultivation in lowlands that had - after similar March 1956 flooding in lowlands (planted after a dry January and February) - prompted hundreds of farmers in Kambo to stop cultivation and/or flee, with the government and Cotonang in turn tightening enforcement and concentration (See Cotonang 1956, Relatório $e$ Contas). The Cotton Export Board had actually proposed in 1948 that certain zones be dropped (Tembo Aluma, Kwango, and Luremo), but this was rejected by the Malanje Governor (DIAS DOS SANTos 1961: 5). These areas of sandy soils were also given the lowest aptitude for cotton by the 1954 soil survey (Gouveia 1956). ${ }^{98}$ Continued high production was desired to recoup the heavy costs of various new deseeding machines and a massive new 18,000-conto cotton seed oil factory opened in late 1957 in Malanje (See Angola Norte, November 30, 1957). Soil conservation works were implemented on nearly 30,000 ha of land (cotton and food) in 1957. «Stabilization», said Cotonang in 1957, was the «object of our utmost attention», and again soil conservation works and «fixation to the land» - in tight collaboration with the state - was emphasized in 1958-60 (СотоNANG (various years) Relatório e Contas). These measures to control erosion and concentrate cotton production in flood-prone lowlands helped boost production to an all-time high in 1958, but at the cost of vulnerability to rains in the next two years. The largest drop in production after the 1960 rains was in Kambo (dropping 43\%). A report after the revolt noted that farmers did not receive assistance designated by law during the 1960 flooding, and «it was on the margins of the Lui River, which forced producers to do two or three plantings each year, where there were the first incidents [of the revolt]».99

98 There major different zones are between Chromic Luvisols (LVx) and Ferralic and Haplic Arenosols (ARf and ARo).

99 Neto, J. (1961) «Apontamento 41: Considerações sobre a cultura algodoeira da Baixa de Cassange», March 14, p. 40 (AHU). 
Figure 12. 1926 cotton gin zones $(25 \mathrm{~km})$

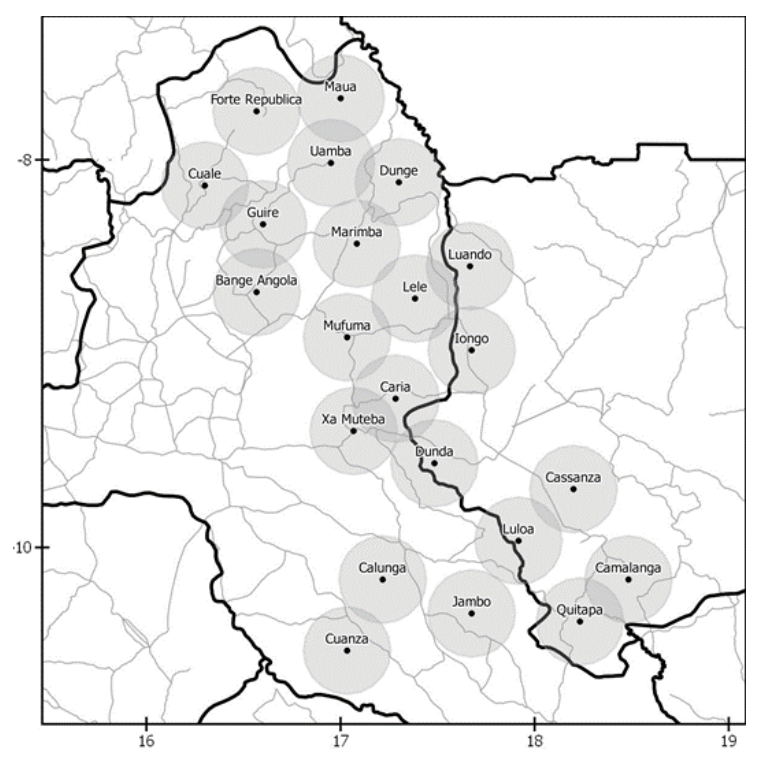

Source: Boletim Oficial, misc.

Figure 13. Survey of village-field distance 1958-1959

\begin{tabular}{|c|c|c|}
\hline Distance of village to field (kms) & $\%$ of 147 Villages ${ }^{a}$ & $\%$ of 475 Villages ${ }^{b}$ \\
\hline$<1$ & $16 \%$ & \multirow{4}{*}{$76 \%$} \\
\hline $1-2$ & $16 \%$ & \\
\hline $2-3$ & $27 \%$ & \\
\hline $3-4$ & $18 \%$ & \\
\hline 4-10 & $18 \%$ & $15 \%$ \\
\hline $10-20$ & $2 \%$ & $8 \%$ \\
\hline $20-30$ & $1 \%$ & $1 \%$ \\
\hline $30-40$ & $0 \%$ & \\
\hline $40-50$ & $1 \%$ & \\
\hline
\end{tabular}

Source: (a) Nunes (1960: 296) (b) Dias dos Santos (1961: 8)

The mixing of material and meaningful, of land, water, and religion, was evident in the way that adhesion to the revolt was reportedly secured through a sort of baptismal pledge in which drops of water were put on people's heads, then a token payment made, gun shots fired, and a cross drawn on the ground..$^{\mathbf{1 0 0}}$ As the pledge holy

100 Antonio Bernardo Cabrita, Report, January 30, 1961, p. 2 (AHU). 
Figure 14. Erosion defense

work at the Canzel cotton concentration, 1954

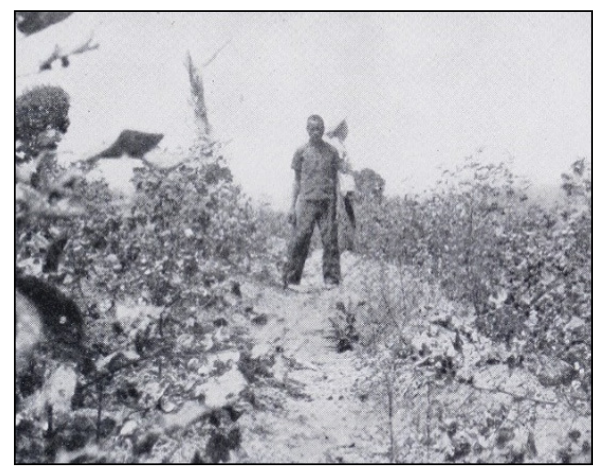

Source: Gouveia (1956: 199)
Figure 15. Transporting Cotonang Equipment through flooded areas of the Baixa

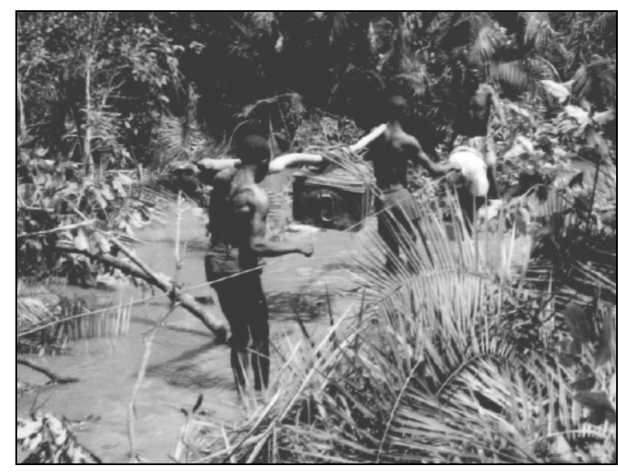

Source: Salazar (1968: vol. 2, 155)

water dripped over their heads like the rivers spreading across Angola that they knew so well, they would try to use the river water that had last year flooded their fields to their advantage this time, planning destruction of bridges and pontoons in order to impede state troops and reprisals.

In addition to susceptibility to flooding, the designation of lowland cotton cultivation areas and the strict planting schedule also entailed heavy labor demands for weeding, another source of grievances. There was thus a combination of structural grievances about long-term hunger produced as women spent increasing time on weeding imperata in the new concentrations) and proximate grievances that December 1960 when men were preparing fields. Being forced to work on heavy lowlands and/or areas infested by the rhizomatic weed imperata could make the work much more arduous than official calculations. ${ }^{101}$ Conducting participant observation research in which I farmed and conversed with farmers in their fields helped give me a closer understanding of imperata - known locally in Kimbundu as «senu» - and prompted me to be more attentive to imperata in the historical records. Gouveia's (1956) soil survey of the Baixa mentions imperata 34 times. Imperata increased

101 As a rhizome, the sharp imperata re-grows if any root material is left over, requiring prolonged fallowing to reduce its prevalence. See also Salazar (1968, vol. 2: 10). 
the heavy labor by men in the initial preparation to clear the weed's dense root mats, as well as by women in rounds of weeding the imperata shoots that will sprout from any small fragment of the weed's root mat. Illustrative of its importance, a known saying at time held that «Seno land is cotton land» (SALAZAR 1968, vol. 1: 32). Colonial and Cotonang administrators may have helped spread imperata by requiring annual burning of cotton plant residues because fires stimulate imperata growth. Administrators required annual burnings of cotton plant stalks in order to reduce pest accumulation in the monocropped fields, and such burnings also required strict adherence to state established planting calendars so as to prevent damage to any still unharvested cotton - it was such a strict calendar that also increased the susceptibility to flooding of early planted fields (MACDoNALD 2004). ${ }^{102}$ It is hardly any coincidence that instructions for revolters in the Baixa de Kassanje were to use the tough stems of imperata to braid belts and bracelets that would help ward off bullets (in conjunction with holy water and incantations of Maria) (SALAZAR 1968: 86). ${ }^{103}$

The work of weeding cotton lands possibly fell largely to women, who the state attempted to compel through their husbands and male heads of households, in a strategy of patriarchal indirect rule. For example, the mandatory passbooks that were required for inhabitants of the Baixa in order for colonial administrators to monitor cotton production put the male head of the household as responsible for the production requirements of the entire family. Although the colonial reports say relatively little explicitly about the roles of gender and women in the revolt, we can attempt to «listen to the silences» and see that this system of patriarchal indirect rule for obligatory cotton production may have resulted in domestic pressures for men to revolt, since they were caught between humiliating and emasculating punishment by the colonial administration, 106 or pushing their wives and family to work to meet quotas and taxes to such an extent that their own families' nutrition and living conditions were harmed.

102 For example, in 1936, all uprooting and burning was supposed to occur from 20-30 September. See Instruções 6, Ordem de Malange n9, October 28, 1935.

103 See also interview with Elisa Kapunga, recounted in Paredes (2015: 216). Senu was also reportedly used for roof thatching and braided dishes (SALAZAR 1968, vol. 1: 119, 154). 
Figure 16. Imperata lowlands, near Luhanda River, between Milando and Kunda dya Baze

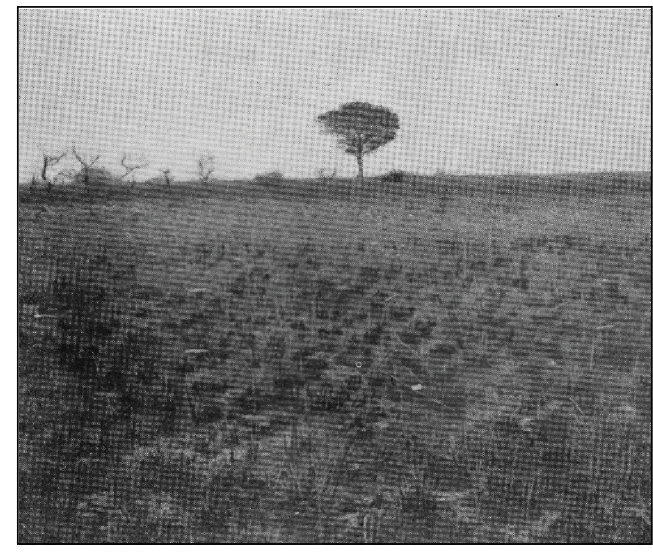

Source: Gouveia (1956: 158)

We also see revolters reject this distinctly patriarchal sort of Portuguese authority. Whereas an initial administrator trying to calm revolters referred to them patronizingly as «my children», the revolt included proliferating shouts and chants debasing such authority by proclaiming the Portuguese state was actually just «bird shit» (Maniputo, tuge ia gingila). ${ }^{\mathbf{1 0 4}}$ Revolt reports seemed taken aback by, and critical of, the unusual assertiveness and lack of obedience by revolters, who are described as threatening, offending, and disrespecting. Relatedly, and perhaps also pertaining to domestic conflicts over different labor contributions to obligatory cotton quotas, revolt prescriptions included an emboldened roles for women in violent encounters: "If a man hits a woman, she will do the same to him and will say reconciliation and peace accomplished» (PALMA, op . cit.). ${ }^{\mathbf{1 0 5}}$ Moreover, the sexual assaults by colonial administrators and African functionaries that were used as punishment or abuse of discretionary authority were also inverted as some revolters threatened administrators' wives in Kunda dya Baze (MARTINS, «Apontamento», op. cit, p. 41. See also KARAJE 2006).

\footnotetext{
104 Pereira, A. (1961) «Informação», Cotonang-Sector de Cunda Ria Base, February 2 (AHU). Also later spelled «Mueneputo».

105 This quote could perhaps also refer to encounters with colonial administrators, but it is listed amongst other measure referring to domestic issues.
} 
The issues just described - labor time conflicts, concentration and spatial restructuring, flooding, and imperata weeds - occurred in relation to one another. And so the revolt seems to have been less sparked initially by a drop in prices paid by Cotonang (as some publications have perhaps mistakenly repeated). In the protestors' own views, as cited in official colonial reports, the emphasis was repeatedly on exactions working for the state, and paying taxes, and being forced to grow cotton, and almost never is price mentioned at all. The immediate material sparks to the revolt were weeding labor demands for the plating season, state census demands, and taxation, while a proximate cause was the preceding year's loss caused by an artificial vulnerability to heavy rains, a vulnerability directly produced by state mandates on village concentration and engineered by state personnel, and which had been part of a larger state spatial project of concentration for decades throughout Angola. Kassanje, rather than reveal effective state delegation to a private enclave, reveals its opposite, namely vast and intensive state spatial concern, intervention and influence.

Similarly, Cotonang's actual concession did not begin as a discrete unit, but rather entailed a transformation from the 1926 legislation that allowed sparse ginning factories with rights to the surrounding areas in a maximum $25 \mathrm{~km}$ radius (later $60 \mathrm{~km}$ ) (see Figure 12 above). As Cotonang cotton production expanded whilst global markets declined during the 1930s, the state emphasized the need for closer regulation of cotton quality, production, and labor. The Portuguese state wanted to encourage investment, and yet balance concerns about unfavorable monopolistic practices and also national versus foreign capture of economic opportunities (Clarence-Smith 1985). From this early period onward, there was increasingly close collaboration between Cotonang and the Portuguese administrative apparatus in the Baixa de Kassanje. The multiple fragmented conces108 sions were re-organized in 1940 from scattered factory-radius zones to concessions that matched administrative districts. Then, by 1947, these were united into what was subsequently known as a singular concession consisting of 12 administrative post areas that covered most of the Baixa de Kassanje. ${ }^{106}$ Cotonang consistently emphasi-

106 The posts were Kwango and Luremo (in the Circunscrição of Kamaxilo), Kambo, Brito Godins, and Tembo Aluma (in Kambo), Songo and Kitapa (in Songo), Kela, 
zed what it referred to as its «collaboration with the authorities», and dozens of detailed pieces of legislation spelled out detailed roles for the state in shaping and participating in Cotonang's activities.

In other words then, the revolt was about the intense and extensive presence of the state in conjunction with the company in the Baixa de Kassanje, and the particular spatial transformations in production, rather than simply low or declining prices paid by an abusive concessionaire. Indeed the actual official nominal producer prices paid to farmers for cotton do not appear to have been declining, though perhaps these official prices were not being paid by Cotonang agents since the real world and colonial prices had been declining (see Figure 17 below).$^{\mathbf{1 0}}$ Moreover, rather than a confined enclave, Cotonang had a regional and international presence - in the shareholders that had direct interests in infrastructure, mining, commerce, etc in the region, in the actual facilities in the cities of Malanje and Luanda, and in the network of cotton business experts in neighboring Congo and elsewhere in Africa and the world. ${ }^{108}$

Lui and Iongo (in Bongdo e Bangala), and Kwale and Forte Republica (in Duque de Bragança). Part of the economics of the concessions was also about coordination, competition, and capacity in the use/control of the de-seeding factories, transport and land. Transport of heavy unseeded cotton was more costly. If a company controlled the de-seeder, it could prevent rival companies from using it, and hence force them to ship heavier cotton and pay more (BGU 1934, n108: 190-191). Also at issue was the full utilization of land, so that concessionaires would not claim more land than they were using for their factories. Investment in processing capacity happened in 1940, after the administrative re-organization. Cotonang reported paying no dividents through 1945 at least, as profits were reinvested in expanding production and processing facilities. Angola (and Congo) used an adapted American variety, Triumph Big Boll. Cotonang's gins and machinery were upgraded and enlarged with new equipment purchased with expanding cotton revenues. Backward linkages from new textile weaving standards by Porto industrialists prompted Cotonang and JEA in 1955-6 to force farmers to switch to a new longer-fiber seed variety that was less productive and differed agronomically (GEORGES 1960). On regional and global historical transformations in the cotton industry, see Beckert (2014), Smith and Cothren (1999), Isaacman and Roberts (1995).

107 Freudenthal (1999: 253) cites Marcum (1969: 124-126) as suggesting cotton prices declined, however it was declines in production that resulted in farmers' declining revenues. Marcum (1969: 126) cites LeMaster's (1962) unsupported statement "Cotton prices had gone down; the workers weren't being paid, and they refused to work».

108 Of note is that Ernesto Vilhena, through the Banco Burnay, held large financial stakes and influential managerial positions in the Luanda-Malanje Railroad, Cotonang, and Diamang. 
The close collaboration between the state and Cotonang agents at the local level encompassed both formalized legal ways, and in informal social ways. Cotonang's reports - internal and published speak frequently about close collaboration with the state. For example, state authorities were responsible for enforcing mandatory acreages, setting cotton prices, delimiting cultivable areas, setting cultivation calendars, mobilizing labor for road work, approving seed varieties, facilitating conservation projects, locating and presiding over markets, and so on. So, the revolt by cotton farmers was not just about abuses by Cotonang as a private concessionaire alone, but rather about the abuses that arose from both explicit stateprivate collaboration as well as state agents' deliberate ignorance, ambiguity and complicity in illegal practices - what Rebocho Vaz, the commanding military officer in Kassanje and later governor of Angola, described as «a great conspiracy of silence» (REBOcHO VAZ 1993: 36).

Figure 17. Cotton price trends, 1939-1960: Angola purchase prices (Minimum and maximum for quality I \& II), and Portuguese Colonial and World Prices (escudos and index)

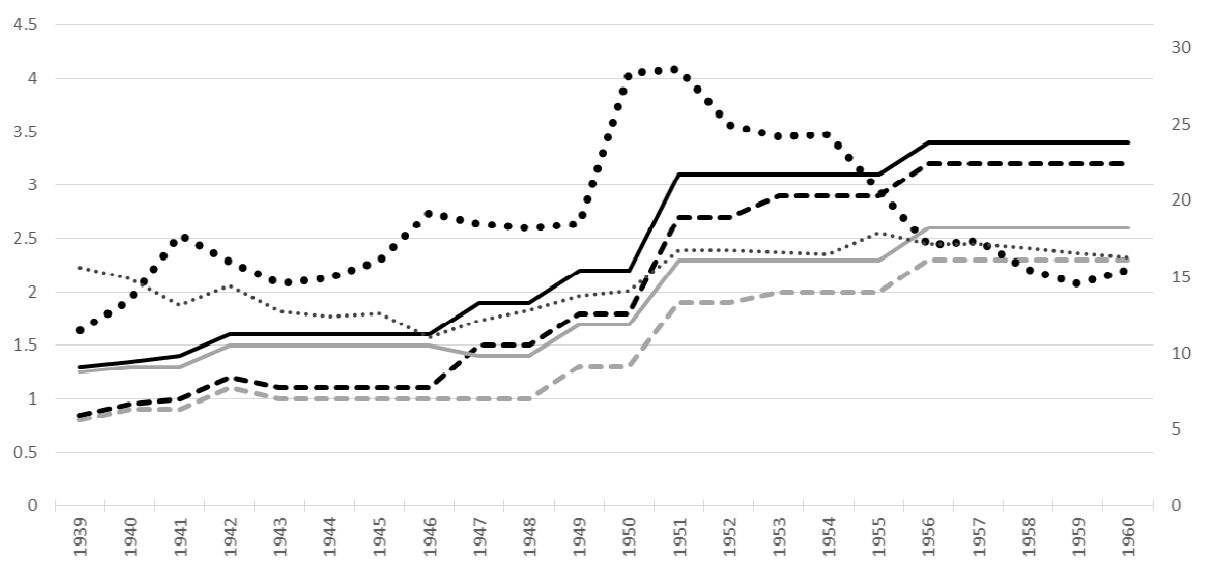

Source: d'Eça (1961: 5); Pitcher (1993: 289)

What was key was that state agents had personal financial incentives to boost production, which they did by various means, because by law they received salary bonuses based on levels of cotton 
production. ${ }^{109}$ So ostentatious were some state agents' conspicuously consumption - evident in ostentatious new houses and cruising cars - based on these cotton bonuses (which could effectively double their salaries) that they were criticized by military commanders called in to quell the revolt. ${ }^{110}$ And the benefits to state agents working in the land of «white gold» had long been recognized. The Malanje Governor noted in 1935 for example that state agents' «greater remuneration obtained in the area of [cotton] intendancy [...] influences the interest with which the authorities follow the march of agricultural operations, and it benefits production» (26). The bonuses prompted greater numbers of functionaries with better qualifications to want to work there, putting strains on other areas, becoming «soflagrant that it could collapse the whole system [...]» In early January, 1961, villagers responded that they would not send people for public works, and «for a long time they had come work for the State, but now they would not do it».111

Cotonang was also required by law to collaborate with the JEA and to fulfill a number of social obligations and labor protection requirements. Informally, Cotonang actively and intensely cultivated high-level political relationships in Lisbon and Luanda (particularly given the emphasis on national industries), but also with ground-level administrators in the cotton growing areas. In the city of Malanje, Cotonang was close with the commercial associations, with the provincial newspaper, and emphasized its paternal relations in «the Cotonang family» (FERREIRA 1948; GEORGES 1955, 1960).

In sum, this article has emphasized a multiplicity of shifting spatial connections in order to re-interpret and explain the 1961 revolt in Kassanje. Understanding these connections is all the more important because of what happened next. The ways in which the colonial

109 Administrators and Chefes de Circunscrições would receive 0.02 Angolars for each kilogram of unprocessed cotton produced in their jurisdiction, Chefes de Posto de Policia Civil would receive 0.04 Angolares, and a technical functionary in the Malanje Agriculture Department monitoring the whole Malanje District would receive 0.01 Angolar, ostensibly to compensate these state agents' for their vigilence and propaganda efforts and trips in promoting cotton production (see Articles 3 and 6 of Diploma Legislativo 276 of 5 November 1931). See also Pélissier (1978: 408).

110 Neto, «Apontamento 41», op. cit., and «Algumas considerações acerca da Zona Algodoeira da Baixa do Cassange», November 29, 1960, pp. 5-6 (AHU).

111 Letter, Alberto M. Quadros, February 6, 1961, p. 2 (AHU); Martins, «Apontamento 34", op. cit., p. 24. 
government and settlers responded with farm mechanization, infrastructure and regional development as counter-insurgency measures would partly shape the post-independence projects, and, ultimately, also now post-2002 national reconstruction.

\section{Some roots of contemporary reconstruction approaches}

Understanding the extensive connections that gave rise to the Kassanje revolt is also important to understanding the subsequent late-colonial spatial development programs that have in turn shaped contemporary reconstruction. Many of the plans for Angola's post-2002 reconstruction of infrastructure were outlined in a massive multi-volume 2025 Long Term Development Strategy, which often drew on comparisons with the late colonial era conditions and regional development plans (cf. PowER 2012). These contemporary projects draw partly on Angolan colonial regional development planning which in turn drew on various currents of thinking, some linked through Brazil to classic French theories, as well as the emerging experience with hydroelectric irrigation projects across Africa. But, in particular, it was after the 1961 revolts in Kassanje, in urban Luanda, and on the coffee plantations in the north, that the spatial experiences of and plans for Angola were laid out in great detail. ${ }^{112}$

Regional economic development inventories and plans were compiled in 1962 in a significant two-volume study by the influential Portuguese economist and planner Walter Marques, then working in the office of Angola's top army commander. Marques subsequently became Angola's Provincial Secretary for Finance and proceeded

112 Explicit post-World War II theorizations of «growth poles» was done most notably in France by the economist François Perroux during the reconstruction period there in 1940 s and 1950s with financing through the Marshall Plan, aiming to emphasize France's eight metropolitan regions to balance out growth with Paris. This approach would arrive in colonial Angola both through Portuguese familiarity with the French analyses and through their international circulation at that time, including a 1961 study, «Angola: Development poles and perspectives», which also situated Angola's emerging hydro-electric and irrigation schemes in relation to Africa more broadly. Such models would also be recirculated and revived in Angola after independence via Brazilian experiences that also drew on Perroux. 
to push through funding for the planned projects. ${ }^{113}$ In a systematic fashion his study inventoried the plans for regional poles and linkages in Angolan development. The study and its approaches were key parts of executing a broader counter-insurgency strategy that was geared around a multi-pronged approach implemented primarily by small local mobile units.

Development poles were part of a broader colonial state spatial program of regional development for counter-insurgency (See PINTO and SAntos 1961; Pinto 1959; SAntos 1960). ${ }^{114}$ This program directly influenced by British and French colonial experience - had as one key plank «social development», as formally outlined in the guiding document, "The Army in Subversive War». ${ }^{\mathbf{1 1 5}}$ In addition to psycho-social action involving culture and propaganda, the social plank emphasized four dimensions: (1) education, (2) sanitary assistance, (3) economic development in agriculture and cattle husbandry, and (4) local infrastructure improvements. Administrative presence throughout the country was significantly increased through increased numbers of posts, and more numerous smaller administrative districts (see Figure 18)..$^{\mathbf{1 1 6}}$

Road construction and logistics would be critical to these activities and to the small mobile local army units tasked with facilitating them. Altogether, the development poles, regional social development, and infrastructure construction laid out as part of late-colonial counter-insurgency would influence the post-independence socialist government's plans, be deliberately targeted by UNITA during

113 The study was published as Marques (1964), though some of the basic parameters of planning and financing were actually drawn up through a series of 5-year colonial development plans, comprising 1953-1958, 1959-1964, 1968-1974, and 1974-1979. These were termed «Planos de Fomento».

114 Perroux's student, Jaques Boudeville, lived in Brazil and published a study on growth poles in Minas Gerais. A French geographer, Michel Rochefort, also strengthened pole thinking in Brazil, and the government began to incorporate these ideas in its policies in the 1960s in order to expand development beyond the concentrations in Rio de Janeiro and São Paulo (SERRA 2003; BunkER 1989).

115 The key points, according to Cann's (1997) account (rather apologetic), that the Portuguese came to emphasize after studying the issue were «minimum force, $c i$ vil military cooperation, intelligence coordination, and small-unit operations» (44). Social development was part of all four. The Portuguese drew on British and French training and experience by territorial organization, with companies based in particular areas, and having small mobile units.

116 Tembo Aluma and Kambo were swiftly reorganized administratively. See Portaria 12195 of April 18, 1962. 
Figure 18. Administrative Divisions and Posts, 1917-1960

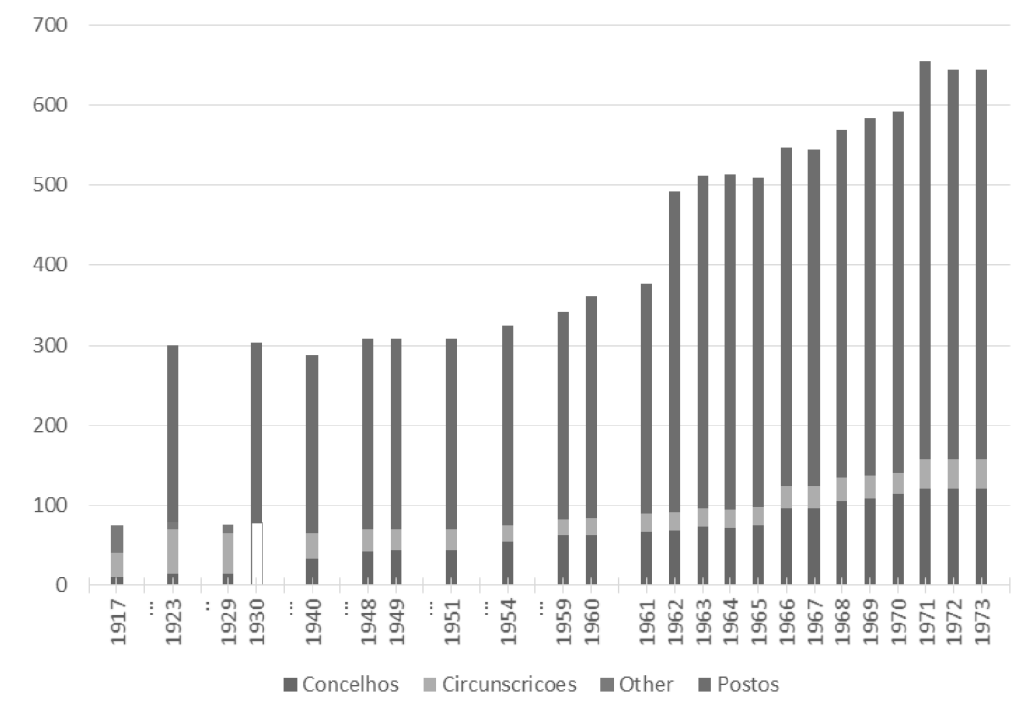

Sources: Anuário Estatístico; Anuário do Império Colonial Português; Amorim (1917)

the war, and then serve as a base to be reconstructed and expanded in the post-war oil-boom era of sub-contracted reconstruction.

The importance of the overlap between military planning and post-1961 regional economic development is also illustrated by the fact that the governor of Angola for the key period 1966-1972 was Lieutenant Coronel Camilo Rebocho Vaz, who was promoted to that position after being the on-the-ground commander of the repression of the 1961 revolts in the Baixa de Kassanje and northern coffee areas (and subsequently being the regional administrator of the rebellious Uije northern coffee district from 1961 to 1966) (See Reвосно VAZ 1993).

It was these sorts of explicitly spatial regional development efforts that were revived with the 1984 contract for the Kapanda hydroelectric dam, for example, in combination with Brazilian influences, but effectively shelved during the war until 2002, when they were reworked again. Since the late 1990 s, nearly a dozen industrial poles have been started, together with four tourism poles. And, in addition to Kapanda, four other agro-industrial poles were started in 2007, with a sixth in 2010, ranging around \$75-97 million each. Such spatial tendencies also found expression in the 2003 Private 
Investment Law, which prioritized seven economic sectors, and divided the country into three different investment zones designed to give incentives for investment in and development of more remote and under-developed areas. In addition to the private investment law, regulations on territorial administration have also categorized different municipalities in to different types, with different structures and different levels of state financing.

Thus, in contrast to portrayals of Angolan economic development as historically rooted only in oil, diamond or plantation enclaves, the actual development plans were acutely aware of and concerned by enclave development and motivated by the threat of growing popular insurgency to address it through a vast, dense spread of infrastructure and economic projects. And this longer, meaningful historical geography goes beyond developmentalist immediate concerns about infrastructure projects in terms of managerial efficiency, corruption of democracy, or economic inequality (SøREIDE 2011), to much deeper and complex sets of processes that have been briefly sketched above.

\section{Conclusion}

The preceding sections showed how people in and around the Baixa de Kassanje revolted against joint state-private coordinated spatial restructuring designed to overcome problems with production and labor management. But it is also important to recognize the nationalist (and not only anti-colonial) aspects of the revolt because that also changes how we understand politics in and of the countryside - consciousness, connections, agency, contradictions, capabilities and so on - then and now. From the records examined so far, there does not emerge a single, totally clear or coherent shared sense of nationalism, but the complex and contradictory nationalist notions more truly reflect the actual context at that time of connections and ferment, rather than strict divisions of space and social groups.

Simply because some parts of the whole complex revolt did not conform to what were later forms of Angolan nationalism does not mean that the revolt did not have nationalist aspects, that it was «only anti-colonial» (See also COOPER 2014). It was a mix, but there were direct links with what many people see as the main forms of modern nationalism, and there were aspects of the revolt that were 
unequivocally clear about political demands for independence for a new supra-ethnic entity in the form of an Angolan nation-state. The above analysis has traced the variety of processes that conjoined to produce the revolt, and consequently the revolt was not always entirely coherent, it was sometimes partial and contradictory, and much remains occluded and yet to be researched.

Nonetheless, from the colonial reports we can see that several key forms of the modern nation-state were invoked during the revolt (in addition to the notions directly linked to UPA and the MPLA), including a new president, capital, government, symbology, and common identity. The new president would be called Kulashingo (which was an old title of a King of the Bangalas). ${ }^{117}$ There are repeated reports that the revolters were asserting that their own government held power, not the Portuguese. ${ }^{\mathbf{1 1 8}}$ Sometimes, contradictorily, this was conflated or merged with the Congo, as in already having «their government headed by Kasavububu [sic]». ${ }^{119}$ Soba Kivota was reported to have said that he and his community "wouldn't pay taxes or follow orders because they already had "their State", which was "Pessa” ( «Informação 216», op. cit.). There was mention of a new capital being at Kasule Kwenda. ${ }^{120}$ The Portuguese flag at Marimba was cut down. Some prominent national symbolism distinct from colonial Portugal seems to have been largely that of PSA, but there are also vague references in the colonial reports to banners and flags. As one report noted, amidst a crowd of 600 armed people in the border town Tembo Aluma at the end of January, "one of the indigenous exhibited, as if it was a flag, a 1960 calendar edited by $P S A »{ }^{121}$

Since there are hardly any Kimbundu statements transcribed in known colonial reports on the revolt, it is hard to tell to what extent the revolters used the language of «nation» or «nação», which has loose translation in Kimbundu as people («muntu»), or people of 116 the land («akwa'xi») (MAIA 1994). What does come across clearly

117 J. M. Pereira de Carvalho, Letter \#543, February 27, 1961 (AHU). According to Marcum, citing Neto (1966), Kulaxingo was captured in March with Mariano near Luremo.

118 See Apontamento 14, op cit, p. See Vicente's report 16th of January «Considerações sôbre a situação actual da região do Milando».

119 J. M. Pereira de Carvalho, «Situação na Baixa de Cassange», Letter \#250, January 27, 1951 (AHU).

120 J. M. Pereira de Carvalho, Letter \#543, February 27, 1961 (AHU).

121 «Informação 144», February 6, 1961 (AHU). 
though is that the revolters thought of themselves as Angolans, as having a broad new common non-local identity going beyond older ethnic identifications and distinct from the Portuguese. Maria «had been concerned about the suffering of Angolans», and was going to «save the people of Angola». The revolters «were all brothers», it had «become necessary that all Angolans initiate themselves in their religion and adhesion to the liberation movement», and Angola and Portugal would be separated forever (PALMA op. cit.; SALAZAR 1968). The revolt managed to mobilize a significant portion of population, tens of thousands of people, across a large area about half the size of Portugal, who were not asking for reform, not asking for return to old, but rather stating that they were their own entity, if albeit a still unclear one, and one prevented by sheer overwhelming Portuguese firepower.

Given Angola's long history of complex mixes of differing forms of spatial connections - military interventions that were destabilizing, destructive and divisive, but also diaspora connections, and international solidarity - an explicit focus on relational geo-histories can help move beyond exclusionary identity politics and unproductively confrontational international advocacy. This article has used a range of new evidence and approaches to re-examine the 1961 revolt in Baixa de Kassanje and re-interpret it as a transforming crossroads of nationalism rather than a reactionary economic enclave. In so doing, the argument has disrupted conventional narratives about Angolan history that over-emphasize relatively isolated enclaves of wealth extraction, as well as provided an alternative narrative that can actually account for the existence and character of post-1961 regional development efforts as part of extensive counter-insurgency programs. This article has thus helped lay some of the necessary empirical and conceptual foundations for other research on how contemporary rural reconstruction projects emerge out of conjunctures of geo-historical processes associated with settler colonialism, protracted war, socialist restructuring, and leveraged liberalization.

\section{References}

Alberto Joaquim Augusto Santos

1928, Relatório dos reconhecimentos feitos pelo tenente de infantaria Joaquim Augusto Santos Alberto, do posto Sede Tembo Aluma (Olo e Ginga). 
Alves Vasco Lopes

1935, Relatório anual do Governador da Província de Malange, Capitão-Tenente Vasco Lopes Alves, Setembro de 1934 a Dezembro de1935.

Amaral Ilídio do

1960, Aspectos do povoamento branco de Angola. Lisboa, Junta de Investigações do Ultramar.

1968, Luanda. Estudo de geografia urbana. Lisboa, Junta de Investigaçðes do Ultramar.

Amorim Massano de

1917, A divisão administrativa da Província de Angola. Loanda, Imprensa Nacional de Angola.

ANON.

1903, Reconhecimento e ocupação de Malange; As terras de Tembo Aluma, e subsequentes operações militares nas regiões da Jinga e Hollo.

1910, Relatório sôbre as bases de ocupação difinitiva da região entre os Rios Cuango e Huamba.

Antunes Maria José Lobo

2015, Regressos quase perfeitos: Memórias da guerra em Angola, Lisboa, Tinta-da-China.

ArCAuTE Honorio Ruiz de and Raúl Ruiz de Asúa

1961, Por tierras de Angola. Vitória, Seminario.

Assis Jr. António de

1917, Relato dos acontecimentos de Dala Tando e Lucala, Luanda, Tipografia Mamã Tita.

Atkins Guy

1955, "A demographic survey of the Kimbundu-Kongo language border in Angola», Boletim da Sociedade de Geografia de Lisboa (Lisboa), vol. 73, n. os 7-9, pp. 325-347.

BALL Jeremy

2003, "The colossal lie»: The Sociedade Agricola do Cassequel and Portuguese colonial labor policy in Angola, 1899-1977. PhD Dissertation in African History Dissertation, UCLA, Los Angeles.

BAYART Jean-François

1993, The state in Africa: The politics of the belly. London, Longman.

BEATRIz Manuel Guerreiro

1918, A cultura do algodão em Angola: Regiões algodoeiras de Catete e Cassoneca. Loanda: Imprensa Nacional de Angola. 
BiRMINGHAM David

1992, Frontline nationalism in Angola \& Mozambique. Trenton, Africa World Press.

Boone Catherine

2013, Property and political order in Africa: Land rights and the structure of politics. Cambridge, Cambride University Press.

BOURGEOIS Arthur

1985, The Yaka and Suku. Leiden, Brill.

Brown Jacqueline Nassy

2009, Dropping anchor, setting sail: Geographies of race in black Liverpool. Princeton, Princeton University Press.

BuiJTENHuiss Robert

1991, "The revolutionary potential of African peasantries: Some tentative remarks», Working Paper, n. ${ }^{\circ}$ 14, Leiden, African Studies Center.

Bunker S. G.

1989, «Staples, links, and poles in the construction of Regional--Development Theories», Sociological Forum, vol. 4, n. ${ }^{0}$ 4, pp. 589-610.

CABRAL Amílcar

1980, Unity and struggle: Speeches and writings (Texts selected by the PAIGC), translated by Michael Wolfers. London, Heinemann.

1988, Estudos agrários de Amílcar Cabral. Lisbon, Instituto de Investigação Científica Tropical and Instituto Nacional de Estudos e Pesquisa.

Cabral Amílcar Lopes and Fonseca J. P. Concela da 1956, "O estudo do microclima de um armazém em Malanje (Angola)», Anais da Junta das Missões Geográficas e de Investigações do Ultramar, vol. 11, n. ${ }^{\circ}$ 1, pp. 198-225.

CAMACHO Francisco

2002, «Baixa do Cassange: O massacre que veio do céu» [Baixa do Cassange: The massacre that came from the sky]», Grande Reportagem (Lisboa), n. ${ }^{\circ}$ 137, August, pp. 62-74.

CANCELA Luiz

1922a, «Missão Católica do Mussuco», Missões de Angola e Congo, vol. 2, n. ${ }^{\circ}$ 12, pp. 208-211.

1922b, «Trinta léguas á margem do Cuando», Missões de Angola e Congo, vol. 2, n. ${ }^{\circ}$ 6, pp. 125-128.

1923, «Viagem á terra dos Holos», Missões de Angola e Congo, vol. 3 , n. ${ }^{\circ}$, pp. $25^{-27}$. 
CANN John P.

1997, Counterinsurgency in Africa: The Portuguese way of war, 1961-1974. Westport, Greenwood Press.

2011, «Baixa do Cassange: Catalyst for righting a wrong», Revista Militar, n. ${ }^{\circ}$ 2508, pp. 17-47.

2012, "Baixa do Cassange: Ending the abuse of Portuguese Africans», Small Wars \& Insurgencies, vol. 23, n. ${ }^{0}$ 2, pp. 500-516.

2015, Flight plan Africa: Portuguese airpower in counterinsurgency, 1961-1974. Solihull, Helion.

CARdoso Carlos Lopes

1970, Carta étnica de Angola (Esboço). Luanda, Divisão de Etnologia e Etnografia do Instituto de Investigação Científica de Angola.

Carvalho Henrique Augusto Dias de 1890, Ethnographia e historia tradicional dos povos da Lunda. Lisbon.

CAstro Eduardo Gomes de Albuquerque e (ed.)

1974, Angola, portos e transportes, Luanda, Sociedade Tipográfica Portuguêsa, Lda.

CGC - COMPANHIA GERAL DE CONSTRUÇÕES

1939, A Companhia Geral de Construções: Ao serviço do império em Angola, Lisbon, Companhia Geral de Construções.

Chabal Patrick

2002, A history of postcolonial Lusophone Africa. Bloomington, Indiana University Press.

Chasse Fernando Hedviges

2012, O processo dos cinquenta: Tempo e memória (1940-1962), considerações históricas. Lisbon, Edição de Fernando Correia.

Chilcote Ronald H.

1972, Emerging nationalism in Portuguese Africa: Documents. Palo Alto, Hoover Institution Press.

Clarence-Smith William Gervase 1985, The third Portuguese empire, 1825-1975: A study in economic imperialism. Manchester, Manchester University Press.

Cleaveland Todd

2008, Rock solid: African laborers on the diamond mines of the Companhia de Diamantes de Angola (Diamang), 1917-1975. PhD Dissertation. Minneapolis, Deptartment of History, University of Minnesota.

COOPER Frederick

2002, Africa since 1940: The past of the present. Cambridge, Cambridge University Press. 
Corrado Jacopo

2008, The creole elite and the rise of Angolan protonationalism, 1870-1920. Amherst, Cambria Press.

CORREIA Miguel Anacoreta

2009, Viva a malta do liceu! Liceu Nacional Salvador Correia: Uma memória de 90 anos. Luanda and Lisbon, Chá de Caxinde and Pangeia Editores \& Associação de Antigos Alunos do Liceu Salvador.

Costa Cândido Ferreira da 1970, Cem anos dos Missionários do Espírito Santo em Angola (1866-1966). Nova Lisboa.

COTONANG - COMPANHIA GERAL DOS ALGODÕES DE ANGOLA

1960a, Esboço de um programa de desinsectisação da cultura algodoeira na Baixa de Cassange. Lisboa, Companhia Geral dos Algodões de Angola.

196ob, Plano da campanha algodoeira de 196o-1961. Lisboa, Companhia Geral dos Algodões de Angola.

CRCCAU

1961, Conclusões da primeira fase dos trabalhos da Comissão Aspectos imediatos a estudar no seu prosseguimento, 4/61: Comissão de Revisão das Condições de Comercialização do Algodão Ultramarino.

CunHa Faliero

1953, Ocupação social nas zonas algodoeiras. Luanda, Junta de Exportação de Algodão.

D’EÇA Luís Salazar

1961, Remuneração do indígena produtor do algodão em Angola e Moçambique. S. 1., Comissão de Revisão das Condições de Comercialização do Algodão Ultramarino, February.

DeGrassi Aaron

2015, Provisional reconstructions: Geo-Histories of infrastructure and agrarian configuration in Malanje, Angola. PhD Dissertation, Geography, University of California, Berkeley.

DENIS J.

1962, «Ngombe ya tumba: Village holo du haut-Kwango», Bulletin de la Societe Belge d'Etudes Geographiques, vol. 29, n. ${ }^{\circ}$ 1, pp. 33-67.

Dias dos Santos J.M., ver Santos J. M. Dias dos, infra

Diniz José de Oliveira Ferreira

1917, Negócios indígenas: Relatório do ano de 1915. Luanda, Imprensa Nacional de Angola. 
1918, Populações Indígenas de Angola. Coimbra, Coimbra University.

1929, «Da política indígena em Angola. Os impostos indígenas», Boletim Geral das Colónias, n. ${ }^{\circ}$ 47, pp. 136-165.

DSEEG

$1967,3{ }^{\circ}$ Recenseamento geral da População 196o, $1^{\circ}$ Volume. Luanda, Imprensa Nacional de Angola.

DSPCFT

1938, Caminho de ferro Luanda: Numero comemorativo do cinquentenario da inauguração do primero troço de Linha Ferrea em Angola, 31 de Outubro de 1888, 31 de Outubro de 1938. Luanda, Empresa Gráfica de Angola for Direcção dos Serviços de Portos, Caminhos de Ferro e Transportes.

EME - ESTADO MAIOR DO EXÉRCITO

1998, Resenha histórico-militar das campanhas de África, vol. vI, Aspectos da actividade operacional, Tomo I - Angola, Livro 1. Lisbon, Estado-Maior do Exército.

Esteves Emmanuel

2008, «As vias de comunicação e meios de transporte como factores de globalização, de estabilidade política e de transformação económica e social: O caso do Caminho-de-Ferro de Benguela (Benguela) (1889-1950)», in Beatrix Heintze and Achim von Oppen (eds.), Angola on the move: Transport routes, communications and history. Frankfurt am Main, Verlag Otto Lembeck, pp. 99-116.

FANON Frantz

1963, The wretched of the earth. New York, Grove Press.

FERguson James

2006, Global shadows: Africa in the neoliberal world order. Durham, Duke University Press.

FERreira Eugénio Monteiro

1989, As ideias de Kimamuenho: Um intelectual rural do período 1918-1922. Luanda, União dos Escritores Angolanos.

FERREIRA Jayme

1948, Relatório da viagem de inspecção do Snr. Jayme Ferreira a Angola, em 1948. Cotonang, July 7.

FERREIRA Jerónimo

1942, «Heróis desconhecidos», Missões de Angola e Congo, vol. 22, n. ${ }^{\circ} 4$, pp. 328-332, pp. 65-67.

FERreIra Vicente

1927, A situação de Angola, Luanda, Imprensa Nacional. 
Freudenthal Aida

1999, "A Baixa de Cassange: Algodão e revolta», Revista Internacional de Estudos Africanos, n. ${ }^{\mathrm{os}}$ 18-22, pp. 245-283.

2012, "A revolta da Baixa de Kasanje», in ATD (ed.), 1961: Memória de um ano decisivo. Luanda, ATD - Associação Tchiweka de Documentação, pp 11-16.

Gabriel Manuel Nunes

1982, A Diocese de Malanje. Malanje and Braga, Diocese de Malanje and Livraria Editora Pax.

GAGo João

1921, Ocupação na area da Capitania-Mor do Olo e Ginga: Tem um relatório de reconhecimento feito á margem esquerda do Rio Cambo, December 17.

GDM - GOVERNO DO DISTRITO DE MALANGE

1954, Monografia do Distrito de Malange. Malange, Governo do Distrito de Malange.

Georges João da Fonseca

1955, Viagem a Angola do Administrador-Delegado da "Cotonang" em Setembro de 1955. Cotonang, October 19.

1960, Viagem a Angola do Administrador-Delegado: Exposição ao Conselho de Administração. Cotonang, February.

GGA - GOVERNO GERAL DE ANGOLA

1944, Relação geral dos processos organizados para a concessão de terrenos do Estado, desde 1912 até 31 de Dezembro de 1943. Luanda, Imprensa Nacional; Governo Geral de Angola, Repartição Central dos Serviços de Cadastro.

Goswami Manu

2004, Producing India: From colonial economy to national space, Chicago, University of Chicago Press.

Gouveia Domingos H.G.

1956, Reconhecimento da Baixa de Cassanje, Angola. Famalicão, Tipografia Minerva.

HARDIN Rebecca

2011, «Concessionary politics», Current Anthropology, n. ${ }^{\circ} 52$ (S3).

HART Gillian

2002, Disabling globalization: Places of power in post-apartheid South Africa. Berkeley, University of California Press.

Herbst Jeffrey

2000, States and power in Africa: Comparative lessons in authority and control. Princeton, Princeton University Press. 
Higgs Catherine

2012, Chocolate islands: Cocoa, slavery, and colonial Africa. Athens, Ohio University Press.

Holemans K.

1954, «Les carences alimentaires a Kwango", in-8, Tome xxv, Fasc. 3, Brussels, Institut Royal Colonial Belge.

ISAACMAN Allen

1996, Cotton is the mother of poverty: Peasants, work, and rural struggle in colonial Mozambique, 1938-1961. Oxford, James Currey.

ISAACMAN Allen and RoBERTs Richard

1995, Cotton, colonialism and social history in sub-Saharan Africa. London, James Currey.

$J A$

2012, «Henriqueta Mpangu e a tradição Basuku», Jornal de Angola (Luanda), 29 Feb.

JEA

1960, Algumas considerações acerca da Zona Algodoeira da Baixa do Cassange, Delegação de Quela, November 29.

JMGIC - JUNTA DAS MISSÕES GEOGRÁFICAS E DE INVESTIGAÇõES

1948, Atlas de Portugal ultramarino e das grandes viagens portuguesas de descobrimento e expansão. Lisbon, Junta das Missões Geográficas e de Investigações Coloniais.

Johnson Amandous

1929, I Marimbans Land: Forskningar och äventyr i Angola. Stockholm, Hugo Gebers Forlag.

KaH Henry Kam

2009 "Governance and land conflict: The case of Aghem-Wum 1966-2005», in T. N. Fongchingong and J.B. Gemandze (eds.), Cameroon: The stakes and challenges of governance and development. Mankon, Langaa Research \& Publishing CIG, pp 185-198.

Kamabaya Moisés

2003, O renascimento da personalidade africana: História, Luanda, Editorial Nzila.

2007, Os heróis da baixa de Kasanji. Luanda, Editorial Nzila.

KARAJE Maria

2006, A imagem da mulher na trilogia de Camaxilo. Luanda, União dos Escritores Angolanos.

KeEsE Alexander

2004, «Dos abusos às revoltas? Trabalho forçado, reformas portuguesas, política "tradicional" e religião na Baixa de Cassange 
e no Distrito do Congo (Angola), 1957-1961», Africana Studia (Porto), n. ${ }^{\circ}$ 7, pp. 247-276.

KopyToFf Igor

1960, Suku religion: A study in internally induced reinterpretation. PhD Dissertation, Northwestern University, Evanston, 194 pp. 1965, "The Suku of Southwestern Congo», in J.L. Gibbs (ed.), Peoples of Africa, pp 441-477.

1977, Speculations about the internal African frontier, Waltham, Mass.: African Studies Association.

1981, Aghem ethnogenesis and the grassfields ecumene.

1987, «The internal African frontier: The making of African political culture», in Igor Kopytoff (ed.), The African frontier: The reproduction of traditional African societies. Bloomington, Indian University Press, pp. 1-86.

1995, "Anthropology as history: Critiques by our "others"», $A n$ thropology Newsletter, May, pp. 12-13.

KYLE Steven

2005, "The political economy of Angolan growth: Social and regional structure», Review of African Political Economy, vol. 32, n. ${ }^{\text {os }}$ 104-105, pp. 269-293.

LAMAL P.

1954, «L'exode massif des hommes adultes vers Léopoldville: Les Basuku du Territorire de Feshi», Zaïre, n. ${ }^{\circ}$ 4, pp. 365-377. 1965, Basuku et Bayaka: Des Districts Kwango et Kwilu au Congo. Tervuren, Musée Royal de l'Afrique Centrale.

LARA Lúcio

1999, Documentos e comentários para a história do MPLA: Até fev. 1961. Lisboa, Publicações Dom Quixote.

LEFEBVRE Henri

1991 [1978], The production of space, translated by Donald Nicholson-Smith. Oxford, Blackwell.

LeMaster E. Edwin

1962, «I saw the horror in Angola», The Saturday Evening Post, 1962-05-12, pp. 49-56.

Linebaugh Peter and Rediker Marcus

2001, The many-headed hydra: Sailors, slaves, commoners, and the hidden history of the revolutionary Atlantic. Beacon Press.

MaCDOnald Gregory E.

2004, «Cogongrass (Imperata cylindrica) - Biology, ecology, and management», Critical Reviews in Plant Sciences, vol. 23, n. ${ }^{\circ}$, pp. $367-380$. 
Macey David

2012, Frantz Fanon: A biography. London, Verso.

Machado Fernando de Utra

1913, No distrito da Lunda: A ocupação de Cassanje. Relatório do comandante da coluna de operações ao Bondo e Bângala, Fernando de Utra Machado, Governador do distrito. Loanda, Imprensa Nacional.

MaIa António da Silva

1994 (2nd ed.), Dicionário complementar Português-Kimbundu--Kikongo (línguas nativas do centro e norte de Angola). Lisbon, Cooperação Portuguesa.

Marcum John A.

1969, The Angolan revolution: The anatomy of an explosion (1950-1962). Cambridge, Mass., M.I.T. Press.

MARQues Walter

1964, Problemas do desenvolvimento económico de Angola, 2 volumes. Luanda, Junta de Desenvolvimento Industrial; Fundo de Fomento de Produção e Exportação.

Massey Doreen

1994, Space, place, gender. Minneapolis, University of Minnesota Press.

Mateus Dalila Cabrita and Mateus Álvaro

2011, Angola 61, guerra colonial: Causas e consequências: $O 4$ de Fevereiro e o 15 de Março. Alfragide, Texto Editores.

Мван Emmanuel M.

2009, "Popular culture and the resolution of boundary disputes in the Bameda Grassfields of Cameroon", in Toyin Falola and Augustine Agwuele (eds.) Africans and the politics of popular culture. Rochester, University of Rochester Press, pp 84-103.

McVeigh Malcom

1961, The present situation in Angola. New York, American Committee on Africa, July 1, 7pp.

Messiant Christine

1998 "Angola: The challenge of statehood», in David Birmingham and Phyllis Martin (eds.), History of Central Africa: The contemporary years since 1960. London, Longman, pp. 131-166. 2006 [1983], 1961: L'Angola colonial, histoire et société: Les premisses du mouvement nationaliste. Bale, P. Schlettwein Publishing. 
Milheiros Mário

1967, Notas de etnografia angolana. Segunda edição corrigida e anotada. Luanda, Instituto de Investigação Científica de Angola.

\section{Miller Joseph Calder}

1972, Kings and Kinsmen: The Imbangala impact on the Mbundu of Angola. Phd Dissertation, Madison, University of Wiscon$\sin$.

1988, Way of death: Merchant capitalism and the Angolan slave trade, 1730-1830. Madison, University of Wisconsin Press.

MOORMAn Marissa

2008, Intonations: A social history of music and nation in Luanda, Angola, from 1945 to recent times. Athens, Ohio University Press.

Mouta Fernando

1934, "Notícia sobre um curioso tambor dos Mussucos», in Trabalhos do $1 .^{\circ}$ Congresso nacional de antropologia colonial. Porto, Sociedade Portuguesa de Antropologia e Etnologia, pp. 210-212.

Neto Rosário

1966, «Notas e impressões do Kwango: A guerra de Maria». Kinshasa, UPA: A Voz da Revolução 1.

Neves Gustavo Bebiano Baeta

1954, Elementos de informação sobre as actividades da J.E.A. atinentes á valorização económica das zonas algodoeiras e da sua contribuição social e sanitária para o bem estar das populações rurais indígenas. Lisbon, Junta de Exportação de Algodão.

NewitT Malyn 1981, Portugual in Africa. London, Hurst.

NicolaÏ Henri 1963, Le Kwilu: Étude géographique d’une région congolaise. Brussels, Edition CEMUBAC.

NunEs António Lopes Pires

2005, Angola 1961: Da Baixa do Cassange a Nambuangongo. Lisbon, Prefácio Editora.

Nunes José António Pereira

1960, «A alimentação na Baixa de Cassange: Inquéritos de consumo e nutricionais, campanhas alimentares e obras de fomento», Anais do Instituto de Medicina Tropical, vol. 17, n.os 1-2, pp. 283-246. 
OLIVEIRA Ricardo Soares de

2013, "O governo está aqui": Post-war state-making in the Angolan periphery», Politique Africaine (Paris), vol. $130, \mathrm{n} .{ }^{\circ}$ 2, pp. 165-187.

2015, Magnificent and beggar land: Angola since the civil war. London, Hurst \& Company.

OpPen Achim von

1993, Terms of trade and terms of trust: The history and contexts of pre-colonial market production around the Upper Zambezi and Kasai, Munster, LiT Verlag.

OsóRIo Jr. Vaz

1921, Relatório da coluna de operações a Uamba até Tembo Aluma (Olo e Ginga), Malange.

PAIGE Jeffrey M.

1975, Agrarian revolution: Social movements and export agriculture in the underdeveloped world. New York, Free Press.

PAREDEs Margarida

2015, Combater duas vezes: Mulheres na luta armada em Angola. Vila do Conde, Verso da História.

PÉLISSIER René

1978, La colonie du minotaure: Nationalismes et révoltes en Angola, 1926-1961. Orgeval, Montamets, Éditions Pélissier.

1986, História das campanhas de Angola: Resistência e revoltas 1845-1941. Lisbon, Editorial Estampa.

PInTo L. M. Teixeira

1959, Problemas do desenvolvimento de África Tropical.

PinTo L. M. Teixeira and SAntos Rui Martins dos (eds.)

1961, Angola, pólos e perspectivas de desenvolvimento. Lisboa, Gabinete de Investigações Económicas do Instituto Superior de Ciências Económicas e Financeiras.

\section{Pitcher M. Anne}

1991, «Sowing the seeds of failure: Early Portuguese cotton growing attempts in Angola and Mozambique, 1820-1926», Journal of Southern African Studies.

1993, Politics in the Portuguese empire: The state, industry and cotton, 1926-1974. Oxford, Clarendon Press.

POLANAH Luís

1970, «O centro de formação agrária da Missão Católica dos Bângalas», Reordenamento, n. ${ }^{\circ} 15, \mathrm{pp} .8-14$.

Power Marcus

2012, "Angola 2025: The future of the "World's Richest Poor 
Country" as seen through a Chinese rear-view mirror», Antipode, vol. 44, n. ${ }^{\circ}$ 3, pp. 993-1014.

Ramos Francisco Pinto

1970, Resumo sinóptico de legislação da Província de Angola.

Viseu, Tipografia Guerra.

Rевосно Vaz Camilo Augusto de Miranda, ver Vaz Camilo Augusto de Miranda Rebocho, infra

REDinHa José

1971a, Distribuição étnica de Angola. Luanda, Centro de Informação e Turismo de Angola, 35pp.

1971b, «Ngur ia Kama: Antiga soberana dos Mussucos», Boletim

Cultural de Luanda, n. ${ }^{\circ}$ 32, pp. 19-22.

RENo William

2011, Warfare in independent Africa. Cambridge, Cambridge University Press.

RiBAs Oscar

1969, Uanga: Feitiço, romance folclórico angolano. Luanda, Tipografia Angolana.

Rocha Edmundo

1998, O Clube Marítimo Africano. Lisbon, Grafilinha.

Ross Edward Alsworth

1925, Report on employment of native labor in Portuguese Africa. New York, Abbott Press.

SALAZAR Sigurd von Willer

1968, Bondos e Bângalas, Dissertation. Lisboa, Instituto Superior de Ciências Sociais e Políticas Ultramarinas, Universidade Técnica de Lisboa.

SANTOS Eduardo dos

1972, Movimentos proféticos e mágicos em Angola. Lisbon, Imprensa Nacional-Casa da Moeda.

SAntos Egídio Sousa

2005, A cidade de Malanje na história de Angola: Dos finais do século XIX ate 1975. Luanda, Editorial Nzila.

SANTOS J. M. Dias dos

1960, Algumas considerações sôbre as necessidades de mão de obra para a cultura algodoeira na Baixa de Cassange, CICA.

SANTOS Oliveira

1927, Resposta às acusações que o americano Professor Edward Elsworth Ross fez à Administração dos Portugueses em Angola num relatório que enviou à S.D.M. em 1925. Luanda, Imprensa Nacional, $125 \mathrm{pp}$. 
SANTOS Rui Martins dos

1960, Alguns pólos do desenvolvimento económico africano. Lisboa.

SARMEnTo Veríssimo de Gouveia

1916, Operações militares nas regiões do Xinge e Lunda: Relatório do governador do distrito, Verissimo de Gouveia Sarmento, Janeiro a Junho de 1906. Loanda, Imprensa Nacional de Angola.

SchmidT Elizabeth

2005, Mobilizing the masses: Gender, ethnicity, and class in the nationalist movement in Guinea, 1939-1958. Portsmouth, Heinemann.

SERra M. A.

2003, "Development pole theory and the Brazilian Amazon», Estudos Economicos, vol. 33, n. ${ }^{\circ}$ 1, pp. 71-113.

Silveira Anabela

2013, «A Baixa de Cassange: O prenúncio da luta armada», Revista Porto, vol. 3, n. ${ }^{\circ}$ 2, pp. 39-57.

SoARes de Oliveira Ricardo, ver Oliveira Ricardo Soares de, supra

Søreide Tina

2011, «Public construction projects-Angola. A need to fortify the barriers against corruption», Angola Brief, n. ${ }^{\circ}$ 5, Bergen, Chr. Michelsen Institute.

Terretta Meredith

2013, Nation of outlaws, state of violence: Nationalism, grassfields tradition, and state building in Cameroon. Athens, Ohio University Press.

THISSEN Leonardo 1960, «Os povos em contacto com a missão de Mussuco», Portugal em Africa (Lisboa), n. ${ }^{\circ}$ 17, pp. 156-168.

VALDEZ Henrique

130 1932, Culturas algodoeiras indígenas. Malange.

Valle Eugénio Torre do and CASTRo José Velloso 1908, Reconhecimento do Rio Cambo. Lisbon, Typographia Universal.

VANDERSTAETEn Louis-François

2001, La répression de la révolte des Pende du Kwango en 1931. Brussels, Académie Royale de Sciences d'Outre-Mer. 
VAz Camilo Augusto de Miranda Rebocho

1993, Norte de Angola 1961: A verdade e os mitos: Baixa de Cassange, Aldeia Viçosa/Colua,Caxito/Fazenda Tentativa, 3a/4a/5a/7a Companhias Caçadores Especiais. Coimbra, Edição do Autor.

VELLUT Jean-Luc

1972, «Notes sure le lunda et la frontiere luso-africaine», Études d'Histoire africaine (Kinshasa), n. ${ }^{\circ}$ 3, pp. 61-166.

2006, «Angola-Congo. L'invention de la frontière du Lunda (1889-1893)», Africana Studia (Porto), n. ${ }^{\circ}$ 9, pp. 159-189.

VICENTE Júlio Cacheira

1959, Considerações úteis sobre a circunscrição do Cambo e a «tribu Holo» e futuro algodoeiro das mesmas, 6 November.

VICENTE São

2011, "Agostinho Neto e a liderança da luta pela independência de Angola, 1945-1975", in Maria Eugénia Neto, Irene Neto and São Vicente (eds.), Agostinho Neto e a libertação de Angola, 1949-1974: Arquivos da PIDE-DGS, Volume I (1949-1960). Luanda, Fundação António Agostinho Neto, pp. 7-482.

VIDAL Nuno

2002, Post-modern patrimonialism in Africa: The genesis and development of the Angolan political system. PhD Dissertation, Kings College, London.

VIEIRA-Martinez Carolyn

2006, Building Kimbundu: Historical language communities reconsidered in Central Africa, c. 1500-1750. PhD Dissertation, African History. Los Angeles, University of California.

Vos Jelmer Antoon

2014, "Work in times of slavery, colonialism, and civil war: Labor relations in Angola from 1800 to 2000", History in Africa, n. ${ }^{\circ} 41$, pp. 363-385.

2015, Kongo in the Age of Empire, 186o-1913: The Breakdown of a Moral Order. Madison, University of Wisconsin Press.

WEIss Herbert F.

1967, Political protest in the Congo: The Parti Solidaire Africain during the independence struggle. Princeton, Princeton University Press.

Wheeler Douglas L. and PéLissier René (eds.) 1971, Angola. New York, Praeger.

WRIGHT George 1997, The destruction of a nation: United States' policy towards Angola since 1945. London, Pluto Press. 


\title{
ZAU Filipe
}

2005, Marítimos africanos e um clube com história. Lisbon, Universitária Editora.

Artigo solicitado ao Autor

Recepção do manuscrito: 23/01/2016

Aceite para publicação: 25/04/2016

Título: Repensando a revolta da Baixa de Kassange de 1961: Rumo a uma geo-história relacional de Angola

Resumo: Através de uma reinterpretação geográfica e relacional do início da luta armada nacionalista em Angola, este artigo ajuda a criticar e ir além das interpretações comuns de Angola (e da África em geral), caracterizada por antigas divisões socio-espaciais. Em vez de um protesto económico num enclave, a chamada «revolta do algodão» continha de facto vários aspectos - alguns explicitamente nacionalistas - de uma mobilização forjada através de múltiplas ligações entre zonas urbanas e rurais, de Malanje e Luanda, bem como entre Angola e o recém-independente Congo. A revolta ocorreu no cruzamento transformador de Malanje enquanto rede política subterrânea de Luanda-Malanje, envolvendo igrejas, trabalhadores contratados e pessoal administrativo, que se cruzaram com a mobilização política provincial baseada no Congo e organizada através de laços transfronteiriços. Essas redes nacionalistas combinadas articulavam-se principalmente, mas não exclusivamente, com camponeses descontentes que enfrentavam tentativas conjuntas de empresas estatais de usar o trabalho intensificado, a reestruturação espacial, o controle e os riscos para superar a resistência e estagnar a produção de algodão. Esses padrões e as formas como o governo colonial e os colonos responderam com mecanização agrícola, infra-estrutura e desenvolvimento regional como medidas de contra-insurgência em parte afectariam projectos de desenvolvimento rural pósindependência e, em última instância, também agora a reconstrução nacional pós-2002. Repensar a revolta da Baixa de Kassanje em termos relacionais, geográficos e históricos permite uma compreensão mais precisa das trajectórias das economias políticas angolana e africana e, portanto, caminhos eficazes para uma mudança social progressiva.

Palavras-chave: Angola, nacionalismo, rural, Geografia, algodão.

\begin{abstract}
Aharon de Grassi
Completed his bachelor's degree in International Development at the University of California, Berkeley, United States of America, in 2000, followed by a master's degree also in International Development, at the Institute of Development Studies at the University of Sussex in 2004, and a doctorate in Geography at Berkeley in 2015. He works with international organizations, teaches at universities, conducts research in various African countries, and contributes to news media.
\end{abstract}


Some of his important works are:

- Provisional reconstructions: Infrastructure and agrarian configuration in Malanje, Angola, PhD Dissertation, Department of Geography, University of California, Berkeley, 2015;

- Contributor, Hunger Free Scorecard: Who's really fighting hunger, Johannesburg: ActionAid International (Jo Walker primary author), 2010;

- «"Neopatrimonialism" and African agricultural development: Contributions and limitations of a contested concept», African Studies Review, vol. 51, n. ${ }^{\circ}$ 3, 2008, pp. 107-133;

- «Envisioning futures of African agriculture: Representation, power and socially constituted time», Progress in Development Studies, vol. 7, n. $^{\circ}$ 2, 2007, pp. 79-98;

- Linking research and policy: The case of Ghana's rice trade policy, Washington (DC), International Food Policy Research Institute, 2007 [ «Ghana Strategy Support Program Background Paper»; 10];

- «Transport, poverty, and agrarian change in Africa: Models, mechanisms and new ways forward», IDS Bulletin, vol. 36, n. $^{\circ}$ 2, 2005 , pp. 52-57;

- with Ian Scoones, Stephen Devereux, and Laurence Haddad (eds), Special Issue: «New directions for African agriculture», IDS Bulletin, vol. 36, n. ${ }^{\circ}$ 2, 2005, pp. 1-143;

- with Steven Wiggins, Food security options in Mozambique: One country, two worlds? London, Forum for Food Security in Southern Africa, Overseas Development Institute, 2004 [ «Country food security options paper»; 3];

- Genetically modified crops and sustainable poverty alleviation in Sub-Saharan Africa: An assessment of current evidence. Accra, Third World Network-Africa, 2003;

- «(Mis)Understanding change in agro-environmental technology in Africa: Charting and refuting the myth of population-induced nreakdown», in T. Zeleza and I. Kakoma (eds), In search of modernity: Science and technology in Africa. Trenton, Africa World Press, 2003, pp. 473-505.

[e-mail: adegrassi@gmail.com] 